\title{
Amusements of Worcester School Children
}

\section{T. R. Croswell}

To cite this article: T. R. Croswell (1899) Amusements of Worcester School Children, The Pedagogical Seminary, 6:3, 314-371, DOI: 10.1080/08919402.1899.10532967

To link to this article: http://dx.doi.org/10.1080/08919402.1899.10532967

曲 Published online: 28 Aug 2012.

Submit your article to this journal $\pi$

Џlll Article views: 3

Q View related articles $₫$

Citing articles: 3 View citing articles ๘ 
By T. R. Croswelir.

Educators are coming more widely to recognize that development following nature's laws is not always a steady growth in one direction, but often by sudden starts and rapid shoots at what are termed the nascent periods. They also recognize that, to guide the formation of true men and women, they must know more of what these nascent periods are, of what the natural tendencies of the child are in the normal process of his development. Such beliefs have led to the many attempts to study in a variety of ways the natural interests of children. The present study is but another such attempt based on the belief that the spontaneous activity of the child affords the best opportunity for the investigation of interest. It is not expected that the most careful study of the outward expression of the life of a limited number of children can settle the problem of children's interests; but we believe that this study, touching as it does the lives of several thousand children now attending our public schools, may serve some as a rough criterion of their work, confirming in many cases the results of general observation and honest experimentation, and in other directions pointing just as directly toward vital errors. Not only will it serve as a criterion of value, but will also contain many hints to the thoughtful teacher for special devices and methods of teaching.

This paper, originally intended as a preparation for a more extended study (which may yet follow), is based almost entirely upon the answers of some two thousand children in the public schools of Worcester, Massachusetts, to questionnaire No. VIII, issued in the fall of 1896 at Clark University. But these answers have been confirmed, as far as possible, by comparison with similar studies of about the same number of pupils from other localities, by the extended reading along this line, and by general observation. For the generous aid received, the writer feels under the greatest obligation to all contributors, and especially to the hearty co-operation and encouragement of Supt. C. F. Carroll, and of those principals and teachers who so kindly furthered the work in Worcester.

These returns, in round numbers, from about one thousand of each sex, include all grades from the kindergarten up to 
and into the high school. They are from seven different schools, so selected that about a third of the children are of Swedish parentage, one-fourth of American parentage, and the rest are about equally divided between the French Canadians and Irish, with a slight sprinkling of other nationalities. The questions were intended to recall as far as possible each child's own experience without suggesting particular answers. In order to call out the various reactions of the child, the questions were put from a number of slightly different standpoints. For the most part the answers bear the stamp of originality and truthfulness.

In collating this material three general heads have been followed :

1. A study of the variety and character of the games, toys, and other amusements of the child. In brief a tabulation and study under a general head of all the things mentioned in the answers to the following questions.

\section{TOPICAL SYLLABI FOR CHILD STUDY. \\ (Series for Academic Year I8g6-7.)}

\section{SPONTANROUSLY INVENThD TOYS AND AMUSEManis.}

A. For Children. (Teachers are requested to ask their pupils to answer this part of the syllabus.)

Write your (a) name, (b) age, (c) sex, and (d) state whether you live in city or country.

I. What toys or playthings do you use most $(a)$ in winter, $(b)$ in spring, $(c)$ in summer, $(d)$ in fall?

II. What games and plays do you play most $(a)$ in winter, $(b)$ in spring, $(c)$ in summer, $(d)$ in fall?

III. Which of these are $(a)$ your favorite playthings, $(b)$ your favorite plays? Do you use most the toys and games you like best? If not, why not?

IV. Name other (a) games, and (b) playthings which you used when younger. Give age at which each was used most. Show your choice as above.

VIII. Describe any games you or your friends have invented. How long did you play them belore giving them up? To what extent did other children imitate them?

IX. What do you play, or how do yoi amuse yourself $(a)$ when alone? (b) When only two or three are together? (c) When more than three?

$X$. What do you do for amusement evenings?

$\mathrm{XI}$. What games do you play on Sunday? What else do you do to amuse yourself?

2. A more careful study of question IX, i. e., a study of the influence which special conditions of environment may exert.

3. A study of the creative work of the child when left to himself. Based upon answers to the following questions :

V. Describe any plaything, no matter how poor, which (a) you have ever made, $(b)$ your friends have made. 
VII. Describe anything you have repeatedly attempted to make, or wanted to do, but did not know how.

Below the fourth grade, owing to the difficulty in written expression, little was attempted beyond the answers to the first three questions. Those from the kindergarten and first grade were obtained by careful inquiry on the part of several teachers who very kindly took upon themselves the labor of writing down the statements of their pupils.

The 2,000 children mention over 700 different means of amusement. ${ }^{1}$

About 100 of these are sedentary games (chiefly cards), and I 50 are with toys and common objects used as toys, which would tend to sedentary habits; 225 are active games or sports; 85 are such pastimes or employment as do not belong distinctively to any of these classes; while the writer was unable to find out even the nature of 130. 272 of these amusements were common to both sexes, I 82 are mentioned by the boys alone, and 197 by the girls alone.

It has seemed best, however, to attempt to classify the amusements according to their most prominent function in the development of the child, ${ }^{2}$ and to present the list at the beginning

1 Space does not permit a description of these various amusements, but the works referred to at the close of this article describe the majority of those which are neither original or parely local.

- 2 Although the classification given in Groos's The Play of Animals seemed to me very unsatisfactory and incomplete, that in his later work, Die Spiele der Menschen, is by far the most philosophical that I have seen, and had it appeared earlier it certainly would have influenced greatly my own work. However, as my manuscript was already in the hands of the printer, it seemed best to call attention merely to the main points of his classification. Assuming, as I have done, that the function of play is development, Groos has made two main divisions of the play activities: In the first, those instincts tending toward the physical and mental development of the individual, find expression; in the second, those tending toward social development. (I. Triebe erster Ordnung oder spielendes Experimentiren. Solchen Trieben, durch deren Einubung das Individuum zunächst einmal die Herrschaft über seinen eigenen psycho-physischen Organismus gewinnt, ohne dass dabei schon die Rücksicht auf sein Verhalten zu anderen Individuen in Vorgrund stände. II. Die spielende Bethätigung der Triebe zweiter Ordung. Solchen Trieben, die gerade darauf ausgehen, das Verhalten des Lebenwesens $z u$ anderen Lebenwesen zu regeln). The first division is subdivided into three main groups, treating respectively of the exercise through play, of the sensory, the motor, and the higher psychic instincts of the individual. The second division has four main groups : Contests, Love Plays, Imitation Plays, and Social Plays. The last group, however, seems to me to be rather an extra emphasis given to the main characteristic of the preceding three, than an exclasive group. Althongh, perhaps Groos's classification is more logical and philosophical than my own, the reader would, I think, find greater difficulty in applying it successfully to the list of activities here presented. 
of this study. Accordingly, in one main class are placed those activities, aiding most directly in the motor development; in the other class those productive of general idea not distinctively motor. These main divisions have been subdivided into groups more or less artificial, but serving to place before us kindred activities of the child, and thus affording a means of mass comparison. After every attempt at identification more than 125 different games must be left unclassified. However, as the most of these are not mentioned by more than one or two different persons, they have little bearing on the comparison of groups, though as indicating the great variety of amusements found among children similarly environed, they have considerable interest. A separate division is also made for those amusements reported by the childen as played only when they were younger.

The general form of presenting each group is in three paragraphs; the first containing amusements mentioned by both boys and girls, the second by boys alone, the third by girls alone. In these paragraphs the amusements are arranged for the most part in the order of times mentioned in the returus, and after each game are numerals giving its standing, thus: Tag B $356-73, G 442-93$, shows that 356 boys out of a total of $I, \infty 00$ speak of playing tag, and 73 of these 356 considered it a favorite, while 442 girls out of 929 play it, and with 93 it is a favorite.

\section{A. Amusements Productive of General Ideas.}

\section{Original Make-believe Games.}

Play House B 59-5, G 365-54; Play School B 69-r, G 257-32; Play Horse B 166-26, G 47-3; Play War B 55-3, G 8- 1 ; Play Fire B 4I-9, G 3; Play Church B 4, G 9; Play Sunday School B 4, G ro; Santa Claus B 4, G 3-I; Salvation Army B 4, G 6; Dress Up B 3, G 6; Policeman B I5-I, $G$ 2; Farmer B 3, G I; Milkman B I, G 3; Doctor $B$ I, G I; Indians $B$ Io-I, G I; Bear B I3 "when younger," G I3; Pig, including "Pig Pen" and "Pig Stabbing" B 4, G 3; Fish B I, G I; Toll Gate B 3, G I; Show, Circus, etc. B 4, G 7; Horse Car B I, G I.

By Boys Alone. Play Ice Cart Io, Ragman 3, Peddler I, Judge 4-I, Mail Car 2, Shoemaker I, Library I, Dutchy-Greenhorn I, Clown I, Daddy I, Dungeon I, Clubroom I, Robbers 2, "Deliver your Goods" 2, "There's a Burglar in the Parlor" $I$, Wildmen and Tiger $I$, Buffalo $I$, Indians and Wild Horse $r$, Indians and Cowboys 4 , Indians and Robbers I, Monkey 3 , Training I.

By Girls Alone. Play Parties, Tea Party, Doll Party 5, Theater 5, Giant 2, Postman, Stage Coach, Fairy Queen, Prince, Lady, Dressmaker, Milliner, Marching, Band, Queens, one each.

\section{Play with Toys.}

Dolls B 39-6, G 621-233; Teaset B 8, G 242-73; Doll Carriage B 5, G 233-80; Doll Furniture B 3, G 79-30; Doll Cradle B I, G 131; Doll Table B I, G I5-I; Stove B I, G I5-3. 
By Girls Alone. Doll Bureau 16-4, Doll Piano 8-4, Dolls' Clothes 3, Flatiron 5, Washing Set I, Sewing Box 3, Doll House 3-I, Doll Swing 2, Doll Slippers I.

Horse B I7-I, G 4; Sheep B 2, G I; Dog B 2, G I. The following are mentioned by Boys alone, although several girls speak of having played with such toys at an earlier age. Elephant, Crocodile, Monkey, Wooden Pig, one each. Wagon, Express, and Dump Cart B I88-35, G 7; Train, Engine, Cars, B 2I-5, G 8; Blocks B 37-7, G 9; Pea Blower B I5-I, G I; Balloons B 4, G I; Windmill B 2-I, G 2; Whistles B 35-6, G 3; Drum B 3r-8, G 3; Harmonica B r $5-5$, G 4; Horn B $9, G$ 3; Rattle B I, G I.

By Boys Alone. Guns (wooden) I7-3, Knives 17-6, Swords I2-I I, Whip 7, Reins 5, Toy Soldiers 2, Flag I, Cannon I, Boat, Ship 35-3, Water Wheel 4-r, Water Hammer 2-I, Jumping Frog 3-I, Fighters (clothespin) 3, Jumping Jack 2, Pop Gun I, Squirt Gun I, Dice 7-I, Clapper 7.

By Girls Alone. Jack-in-the-Box 2, Toy Watch 1, Wooden Hammer I, Horse Car I.

\section{With Common Objects Used as Toys.}

Dog B 36-5, G II-3; Cat B I7-2. G 9-I; Horse B 4. G 3; Baby B 2-1, G 3; Leaves B 75-2, G 1 12-6; Flowers B 32-r, G Io2-I; Horse Chesnuts, "Horse Cobbles", B 85-5, G 7; Nuts, Nutting B 48-x, G 28; Trees, Climbing Trees B 25-I, G II; Apples B 18, G 8; Berries, Berrying B 16, G 6; Picking Fruit B 5; Acorns B 3, G I9; Sap B I, G r; Eat Food B r, G I; Hot Cross Buns B I, G I; Hay, Playing in Hay B 20-3, G 18; Grass B 3I, G 8; Sand Dirt B 21, G I8; Sticks B 18, G I2-I; Stones B 12, G I3; Water B 8, G 3; Fire B 5, G I; Tin Cans B 9, G 7, Tin Dishes B 3; Trunk B 4-I, G 3-I; Bells B 3, G 3; Box B I, G 3; Buttons B 3, G 2; Matches $\mathrm{B}_{4}, \mathrm{G} 3$; Pail $\mathrm{B}_{3}, \mathrm{G}_{3}$; Soap Bubbles $\mathrm{B}_{\mathrm{I}}, \mathrm{G} 3$; Clothespins B I, G I; Broom B I, G I.

By Boys Alone. Pigeons 5, Pigeon Flying I, Birds 2, Parrot I, Poultry Show I, Toads 4, Frogs I, Rabbits 4-I, White Rats 2, Cows 2, Goats 2, Living Animals 2, Pigs I, Lanterns 9, Valentines 8, Jacklanterns 7-I, Fireworks 4, Pot 2, Bench, Bicycle Buttons, Blank Cartridges, Crowbar, Boots, Cartwheel, Wheel, Dust-pan, Fork, Toothpick House, Strops, and Spool of Thread, one each.

By Girls Alone. Mud, Mud Pies, etc., 24-2, Clover, Oakballs, Oranges and Pears, one each; Lamp, Candles 5, Basket 4, Rocking Chair 4, Jacket 2, Parasol 2, Spoons 2, Stamps 2, Bottles, Cap, Coal-hod, Fans, Mother's Skirt, Pillow, Screen, one each.

\section{Occupations Common Among Children.}

IN-DOOR.

Books, Reading B 83-7, G I08-22; Studying B 2, G 3; Camera B 7-2, G I; Drawing, Painting, etc., B 22-2, G 9; Blackboard B 2, G I3; Pencil B 2, G 3; Ruler B I, G I; Slate B 6, G I5; Paper, Paper Cutting, Colored Paper B 4-I, G 4; Desk B I, G 3-2; Talking B 7, G 7; Tell Stories B 4, G I2; Riddles B 4, G 7; Singing B II-I, G 22; Musical Instruments B 20-4, G 60-10; (of these the following are mentioned specifically, Piano B 6-I, G 5I-9; Violin B 5, G I; Banjo B r, G I; Flute B 3; Music Box, Melodeon, Harmonica, Accordion, and Zither, by one boy each; Appollo Harp, Autoharp, Mandolin, by one girl each;) Dance $B$ 4-2, G I5-3; Parties, Social B 4, G 6; Carpentry, Tools, Tool-box, Saw, Hammer and Axe, etc., B 4I-6, G 3; Jack-knife B 12-2, G I.

By Boys Alone. Printing Machine 5-1, Ty pewriter 3; Debating Club, 
Go to Public Lectures, Library, French Book, Bookkeeping, one each; Jig Saw 5, Leather and knives I, Building Log Cabins I; Electric Battery 3, Electric Toys 2, Electric Pulley, Experiments in Electricity or Chemistry, Telephone, Run a Stationary Engine, one each.

By Girls Alone. Writing, Writing Letters 5, Assume Characters and Charades 4-I, Practice Reading, Recite Poetry, Spell, Study Catechism, one each; Microscope. Scales, Theater, Opera 3, Play with Boys I, Fancy Work 15-1, Crochet 15, Sew 19-1, Patch Work 1-1, Make Candy 4, Pop Corn 2, Stove 2, Clean and do Chores I, Collecting Tintypes.

\section{OUT-DOOR.}

Shove1, Hoe, B 6I, G I2-I; Rake B I2, G 3; Wheelbarrow B 18.I, G 2; Gardening, "Tend my Plants," "Plant things in Spring," B 6, G 6; Walks, "Go to Walk" B 14-2, G 25-2; "Go to the Woods to have a Good Time," "Romping in the Woods" B 2, G I; Camping Out B 2, G 2-I; "Fresh Air," "Shovel Snow for an excuse to get out" B I, G I.

By Boys Alone. Butterfly Net 2, Catch Bugs 2, Whooping 2, Collecting Eggs I, Peddle Papers I.

By Girls Alone. Lawn Mower and Hose 2, Picnicing 2, Play in the Sun 2, "I go away for amusement," Go out with the Baby, Dig Potatoes, Look at Birds, Go Shopping, one each.

\section{CARDS.}

Cards B 163-34, G I5I-5I; Old Maids B 38-12, G 73-20; Authors B 28-2, G 50-ro; Peter Coddles B 2, G 15-3; Robinson Crusoe B 8-3, G 7-3; Snap B 6-2, G 8; Anagrams, Letters, Spelling Game B 8, G 5; Napoleon B 6, G I; Lost Heir B 7-I, G I; Chicopee B 7, G I; Bible Game B 2, G 5-I; Dr. Busby B 3, G 3; Christmas Goose B I-I, G 5-4; Cinderella B 3-I, G 3; House That Jack Built B 3, G 2; Jack the Giant Killer B 3, G I-I; Mail Express B I, G I-I; Pussel B I, G 3-I, Whang B I, G 2-I; U. S. Puzzle B 3-I, G I-I; Shopping Game B I, G 3; Waterloo B 2, G 2-I; Literature Game G 3-I; Literary Women B I; Noted Men of America G I; Solitaire B 2, G I; New Market B r, G r; Speculation G 3; Penock G $\mathrm{I}$.

By Boys Alone. Cock Robin, Columbus Base Ball Team, Bluff Cards, Delagoa's Travels, Hispaniola, Princeton and Yale Foot Ball Game, Slap, Massachusetts Puzzle, one each.

By Girls Alone. Louisa 7-3, History Game 4, Auction 3, Flag Game 2-1, Muggins 2, Heedless Tommy 2, Give Away, Everlasting, Geographical Games, Cities of Out Country, Goose Gander, Golden Locks, Game of Progress, Star Game, Desperation, Flower Game, Fortune Teller, Prisoner of Zenda, Rance.

\section{TABLE GAMES.}

Checkers B 277-87, G 189-34; Dominoes B 185-42, G 133-26; Chess B 25-3, G I; Puzzles B 2I-3, G 13-I; Lotto B 2I-4, G 47-8; Go Bang B II-2, G II-4; Tic-tac-too B II-I, G IO-2; Fox and Geese B 4, G I4-I; Halma B 2, G 5-1; Crocinole B 7-1; Parchesi B 17-2, G 40-17; Messenger Boy, Errand Boy, Telegraph Boy, Newsboy, Office Boy B 3I-Io, G 16-4; Nellie Bly, A Trip Around the World, A Race Around the World, Around the World in 8o Days B I7-3, G 7; Backgammon B 1 2-2, G I5-3; O1d Mother Goose B 3, G 14-2; William Tell B 1, G $1_{3}$; Cuckoo B 4-I, G 6; Yacht Race B 5-I, G 2; Steeple Chase B 2, G 4-I; Cash B 3-I, G I; India B 2, G 2; Innocents Abroad $B$, G I; Jack and the Beanstalk B 2, G i; Little Miss Muffit B I, G 3; Zigzag Kangaroo B 2, G I; Bobb B I, G 2; Arena B 1, G 2.

By Boys Alone. Toboggan Slide Game 2, County Fair, Sailor Boy, Three Horse Race, one each. 
By Girls Alone. Crossing the Alps 3-3, Drummer Boy 2, Bicycle Game 2-I, Little Bo-Peep 2-2, Crossing the Ocean, Lost in the Woods, King Quoits, Stick Game, one each.

\section{PARLOR GAMES.}

Hide the Button B I4, G 55-7; Hide the Thimble B 15, G 26-2; Uuaker Meeting B 5, G 10; Guessing Games B ro, G 2; Post Office B 3-1, G 6-3; Shouting Proverbs B I, G 3 .

By Boys Alone. Send my Ship to China 2, My Cook doesn't like Peas I, Jedkins Up I, Ghost I, Kiss the Pillow I, One, Two, Three, Go Back I.

By Girls Alone. Donkey Game 4, Strike an Attitude 4, My Ship Comes Laden with 2, Clap In and Clap Out 2, Buff with the Wand, Fortune Telling Games, Adjective Stories, Hunt the Slipper, My Lady's Toilet, Nonsense, Simple Simon, The Miller, Peek-a-boo.

\section{B. Amusements Productive of Motor Development.}

\section{Traditional Ring Games.}

On the Green Carpet B 6, G 62-10; Grandmother Grey B 5, G 53-10; Go In and Out the Windows ("Winrows") B 4-2, G 40-5; Lazy Maid, Lazy Mary, Lazy Bessie B 2, G 33-2; Water, Water wild Flowers B I, G 33-2; Ring Around the Rosy B 5, plus to at an earlier age, G 3I-5, plus ro earlier; Farmer in the Dell B 8-2, G 26-5; London Bridge B 3 (plus II earlier) G 23-3; Round the Mulberry Bush, "Round the Barley Bush" B 2, G 14; Billy, Billy Button B 5, G I; Three Kings B I, G 4; Jack and Jill B I, G 4; Tin Tin a Poppy Show, or Pin, Pin," etc., B I, G 4 .

By Boys Alone. Bushel of Wheat, Bushel of Rye 2, Fly Ritty through Peals I.

By Girls Alone. Jennie à Jones, Jemima Jones 24-3, Poor Tommy is Dead 14-2, Little Sally Waters 12 (plus 6 earlier), Forty Girls go Round the Ring, “Merry Girls, etc. II-3, Draw a Pail of Water 4, Here come an Old Woman from "Farmerland" (or Cumberland) 5, Here comes one King I, Here's the Way we Wash our Clothes I, Have you any Bread and Wine? 2, Lady Bug, Fly, Fly! I.

\section{Games of Chase.}

Tag B 356-73, G 442-93; Hide-and-Seek B 24I-74, G 427-r32; Relievo B 356-I 26, G 194-48; Black Tom and Black Jack B Io2-26, G 97-14; Drop the Handkerchief B 22-2, rOI-II; Lion in the Den B 4, G 80-22; Puss in the Corner B 35-3, 73-9; Steps B 9, 65-9; Hare and Hound, Hunt the Hare B 65-13, G 6; Blindman's Buff B 42-2, G 64-13; Hill Dill B 45-6; 47-4; Run, Sheep Run, or Sheep Lie Still B 58-ro, G 36-II; Bull in the Ring B 42-7, G I3; Bar Up B 42-6, G 20-2; Snap the Whip B 4I-3, 50-2; Colors B 6, G 40-4; Duck on the Rock B 37-5, G 36-6; Stealing Eggs B 35-3, G 9-I; Birds B 9-I, G 25; Trade B 6, G 23-2; Old Witch ("Oh, Mother the Kettle is Boiling over," "Sunday, Monday," etc., "Old Man") B 6, G I9; Pig Tail B 5, G 18-I; Pinch Me, Oh! B 13-2, G I; Last Couple Out B I, G I2-5; Bonney B 6, G 3; Rachel and Jacob B 6-I, G 3; Chase the Squirrel B 6-1, G 2; Chase the Fox B 2, G 2; Gypsy B 3, G 3; The King ( $I$ 'm on the King's Land) B $I, G$ 2; Lead, Leadman B 2, G 12-I, "Pond, Pond Pull Away," "Pump, Pump Pull away" B I, G I; Rush B 4, G I; Pound the Back B 2-1, G 6-I; Fox, Fox and Goal B 2, G I; Grand Daddy Long Legs (An Original Game of Chase on Stilts) B 2, G I, Skip B 3 , G I. 


\section{Contests with Objects.}

Ball B 679-24I, G 409-67; Marbles B 608-II5, G 130-21; Football B 455-I5I, G I; Jackstones B 28-2, G 34I-63; Hockey, Shinney, Polo B 313, G 8; Top B 176-28, G II; Hop Scotch B 16, G 154-2I; Croquet B 62-3, G 148-52; Hoop B 7I-3, G Iro-14; Stilts B 70-7, G I2; Bean Bag B 4, G 72-7; Pick Knife B 57-4, G 3; Tenpins B 53-10, G 6; Tennis B 51-ro, G 3I-Io; Tip Cat B 33-I, G ro-2; Tiddledy Winks B 22-6, G 3I-3; Pillow Dex B 16-2, G 2I-4; Horse Shoes, Quoits B I9-2, G I; Fish Pond B I2-I, G I5; Pool, Billiards, B 13-2, G 2; Jackstraws B 4, G II; Golf B 4-I, G I; Cricket B 4, G I; Battledore B I, G 3; Bagatelle B 2, G 3; Parlor Ring Toss B I, G I.

By Boys Alone.-Boxing 36-7, Fight for fun I, Fencing r, Sling Shot 22, Bow and Arrow I5-2, Hand Ball 4, Basket 2, Tug of War 5, Vaulting Pole 2, Shovel Board I, Tivoli r, Roly Poly I.

By Girls Alone.-Shooting Game I.

\section{Other Athletic Pastimes.}

Racing, Running B 5I-I3, G 8; Leap frog, "Foot and Half" B 48-8, G I; Jumping B 44-4, G 8; Gymnasium, Gymnasium Apparatus, Dumb bells, Indian Clubs, etc., B 22, G Ir; Poison B 2, G 16-I; Swinging B I3-I, G 22-4; Hurdles B I, G 2; Wall Fences B 2, G I; Bicycle, Tricycle, Velocipede B I60-78, G 9I-46; Swimming B Ir9-26, G I5-2; Kite, Parachute B 107-5, G 12; Fishing B 80-19, G 7-1; Boats, Canoes, Rafts, B 78-18, G 27-4; Guns, Rifles, Hunting B 64-14, G 3; Tents B 33-2, G I4-I; Horseback Riding B 7-I, G 4; Carriage, Sleigh, Buckboard, Tally-ho B r6-5, G 22-3; Sled B 555-100, G 498-69; Skates B 538I68, G 412-II3; Snow Balling B 123-14, G 98-3; Snow Shovel B 65-I, G 19; Snow Shoes, Skees B 58-3, G 1o; Snow Man B 36-3, G 26-I; Snow House B 28-3, G 23-2; Snow Forts B 20-3, G 14; Toboggan B 2, G 2.

By Boys Alone.-Punching Bag 6-I, Wrestling 3, Vaulting 2, I,ast Dare I, Roller Skates I, Traps 4, Ice Boat I.

By Girls Alone.-Jump the Stick 15, Hopping 2, Walk on Cans 2, Sliding on Feet I, Somersaults I, Merry-Go-Round I, Snow Plough 2.

2. Practical Jokes.

Kings and Queens B I, G 2.

By Boys Alone.-Digging for Gold 7, Pee-wea-mo-yet 2, Knight of the Whistle $I$, Let 'er Fly $I$.

C.

\section{r. Games Mentioned Only as Outgrown.}

By Boys Alone-Cuckoo, Devil in the Band Box, Filling bar of soap with tacks, House that Jack Built, Play in the Tubs, Stealing Chickens.

By Girls Alone.-Barker, Drumming on Tin Pans and Marching, Five Little Rabbits, Fox and Cat, Little Boy Blue, Pea Porridge Hot, Peek-a-boo, Peter and Rachel, Roll Your Hands, Selling Birds, Stealing Chickens, The Cobbler, This is the mother good and dear.

\section{Unclassified.}

Attack, Farmer Jones's Pigs; Ducks and Geese, "The Geese, The Geese," Goose in the Garden, Hide the Gig, Happy Family, Mash, Pilgrim's Progress.

By Boys Alone.-Allart, Bombay, Boston Ring, Bug-a-Boo Bill, Catch my Bear, Catch the Wild Bull by the Horns, Catch the Fox by 


\section{AMUSEMENTS OF WORCESTER SCHOOL CHILDREN.}

the Tail, Croweck, Coast in the Well, Dickey Dick, Duckrick, Four Famous Funny Fellows, Four Louse Eaters, Free the Ring, Full Force, Galic, Gig, Mash the Gig, Muzzle the Gig, Gold Bank, Half Eagle, Have you ever seen a nigger, High Giggles, Hill Climbers, Kymo, Lilostillgo, Log Cabin, Man in the Moon, Pat, Peter Pumpkin Eater, Pike's Pike or Bust, Plume, Plump, Pooh, Range, Soldier on the Road, Six and Four are Ten, The Spear, Spole, Stag, Tarband, Tat, The Capitol at Washington, The King Quoth, Three Mice, Tweuty-three Fishers, Twiddles.

By Girls Alone.-All Nations, Are you in it? Babes in the Woods, Bean Stalk, Bean Stalk Stay, Black Jill, Boots without Shoes, Build the Bridge, Cut the Cheese, Demotion, Everlasting March, Feather Deck, Fly little boy, Forfeit, Four and Twenty Blackbirds, Golden Eggs, Gold Spoon, "Halo my children," Happiness, Happy Go Lucky, Have you ever? Hillock, Hunter, King Cole, I'm posted, I went to Paris, Jack-of-All-Trades, "John, John, I'll tell your daddie," Jumbo, Luck, Milk Maid, Minute Man, Mother Hubbard, Musks, Needle and Thread, Pall, Parlor Mantelle, Paws and Claws, Pick me out, Poor Farmer, Princess, Punch and Judy, Rain, rain, rain, Riding Hood, Road to Washington, Rock-a-Bye Baby, Sheep and Dog, Six Sticks, Snake Game, Squirrel, Strategy, Sunstrade, The Poor Cat, Telka, Ticket Office, Tom Old Apple-tree, Tug Away, Twenty-three Dishes, Ward Game, What Katy did at School, Who'11 go to heaven first?

\section{General Function and Characteristics.}

What are the characteristics of such typical amusements as ball, marbles, jumping rope, tag, checkers, cards, dolls, playing horse, cycling, playing with leaves, stones, reading, etc. ? Certain of these are marked by active physical exertion, but this cannot be said of all. Some are dramatic; some call for the exercise and display of varying degrees of skill. Some demand the co-operation of numbers and so necessitate a social community, others are adapted to the individual alone. Some plays are deliberative, others appear to be entirely impulsive. Some amusements satisfy if the individual has the opportunity merely to exercise his own skill, his mastery over self and over inanimate objects, while others necessitate the subordination or mastery of another. In most games the element of chance is present, the risk of not securing the desired end adding zest to the other attractive features of the games.

Most theories offered to explain the play of children begin by assuming a "play impulse" sharply differentiated from all other activities, yet the serious character of much play is a fact of common observation. The necessity of accounting for such an impulse has led many to assume again, as the basis of all play, an exceptional state of neural activity which is termed the condition of "overflow energy." 1 This, perhaps, is the

${ }^{1}$ Friedrich Schiller: Letters upon the Asthetic Education of Man. See letters 25 and 26 .

Herbert Spencer: The Principles of Psychology. N. Y., I897. Vol. II, p. $627 \mathrm{ff}$. 
most widely accepted theory, but it confines play to such physiological conditions as produce an excess of vital energy and also necessitates looking further for an explanation of the character of the resulting activity. It is the theory of animal rather than of human play. It does not give sufficient weight to the fact that both children and animals participate in certain games after a condition of extreme fatigue has been induced. To explain the varying character of the activity, Spencer adds "imitation" of some external act, serving as an extra stimulus at the moment when the pent-up energy is about to discharge. ${ }^{1}$ Groos, accepting this theory as explanatory merely of a condition favorable to play, adds and emphasizes the part played by "instinct:" "Thus we see that the explanation of play by means of the 'overflow-of-energy' theory proves to be unsatisfactory. A condition of superabundant nervous force is always, I must again emphatically reiterate, a favorable one for play, but it is not its motive cause, nor, as I believe, a necessary condition of its existence. Instinct alone is the real foundation for it. Foundation, I say, because all play is not purely instinctive activity. On the contrary, the higher in the scale of existence, the richer and finer becomes the psychological phenomena that supplement the mere natural impulse, ennobling it, elevating it, and tending to conceal it under added detail." 2 According to his theory " the animals do not play because they are young, but they have their youth because they must play." " Others, too, have emphasized "instinct," and through it sought a teleological explanation for the variety in play, while the recapitulation theory helps us to explain movements which seem to have but little to do with later life, on the ground that the child in the process of his development must of necessity reproduce the early history of the race."

Nevertheless, as we consider all the amusements of the child we may, I think, assume that all his activity, be it physical or mental, is always an expression of his psychic life, and that it always reacts upon that life. Such a view of play seems to have been taken by Froebel, James and Wundt. The first sees in play the "self-active representation of the inner-representation of the inner from inner necessity and impulse." finds, in the process of "association of immediate impressions with earlier ideas," the beginnings of an active imagination

${ }^{1}$ Ibid., Vol. II, p. 709.

2 Karl Groos: The Play of Animals, translated by Elizabeth L. Baldwin. N. Y., 1898 . p. 24.

s Ibid., p. 77.

4 Burk, Frederic L. : Teasing and Bullying. Ped. Sem., Vol. IV.

${ }^{5}$ Froebel: Education of Man. International Education Series, N. Y., 18g6. p. 55 . 
which "shows itself with an impulsive force that the child is unable to resist," and this force being unchecked by inhibiting ideas, expresses itself in the varied activities of childhood. How varied this activity may be, when unchecked by inhibiting ideas such as influence adult life, may be apprehended by weighing the following words of James: "Where there is no blocking, there is naturally no hiatus between the thought process and the motor discharge. Movement is the natural immediate effect of feeling, irrespective of what the quality of the feeling may be. It is so in reflex action, it is so in emotional expression, it is so in the voluntary life." The italics are from the original text.

In whatever way Froebel may have conceived his "inner necessity and impulse," it seems impossible of translation into any terms, consistent with modern psychology, which do not also include "the association of immediate impressions with earlier ideas," and with "the thought processes" which form the initiative to action. In this sense the occasion for activity would not be confined to the discharge of motor cells, due exclusively to the general superabundance of neural energy; but would include such a discharge occasioned by great local activity in some psychic center, due to any stimulating agency, though this agency might be merely the stimulating effect of some metabolic process. The latter is the most plausible explanation which we have at present of many of the seemingly impulsive movements in the young, as for example of the vigorous but aimless kicking of the infant, or of the frolicking movement seen in the young animal. But a similar psychic activity with its accompanying motor discharge may be occasioned by varied external stimuli, and may continue far beyond the limits of healthy exercise-examples of which are far too frequent in many forms of nervous disease; and all who have ever experienced the state of "being too tired to rest," will readily recall the almost uncontrollable impulse to motion, although fully realizing the necessity of rest, and being irritated by the slightest disturbing influence.

This explanation of activity does not roughly separate that of the child from that of the adult. In both is found the impulse to action, due to metabolic processes or to the immediate reaction to some objective stimulus, and the deliberate action having some definite end in view. That the one form of stimulus is more frequent at one period of life, does not stamp all the activities of that period as different from those of the other,

\footnotetext{
1 Wundt: Outlines of Psychology. p. 293.

2James: The Principles of Psychology. New York, 1890. Vol. II, p. 526 .
} 
it only changes the emphasis. Such a view does not consider the child simply as a child to be treated as a child; but as a member of the human race who has already begun to take his place in the world where he lives. The school is no longer a mere drill-room-a vestibule to the life which is to follow; but life has already begun there, under conditions very similar to those which affect the teacher and the parent. In adult and child alike there is the psychic life struggling for expression, and in every expression reacting upon the psychic centers, and modifying them. The character of this expression is of the greatest importance, nor is it changed when the child has left the public school; whether he cares for knowledge or not, he will be a learner throughout his entire life.

With this general statement of the function of amusements as at once the expression and the means of psychic development, and without attempting to differentiate the explanation of the play activity from that of general activity, we will return to the consideration of the characteristics of children's amusements as seen in these returns.

The main classification was based on the motor development. The list of amusements calling for active physical exertion is

Amusements tending toward Physical Development.

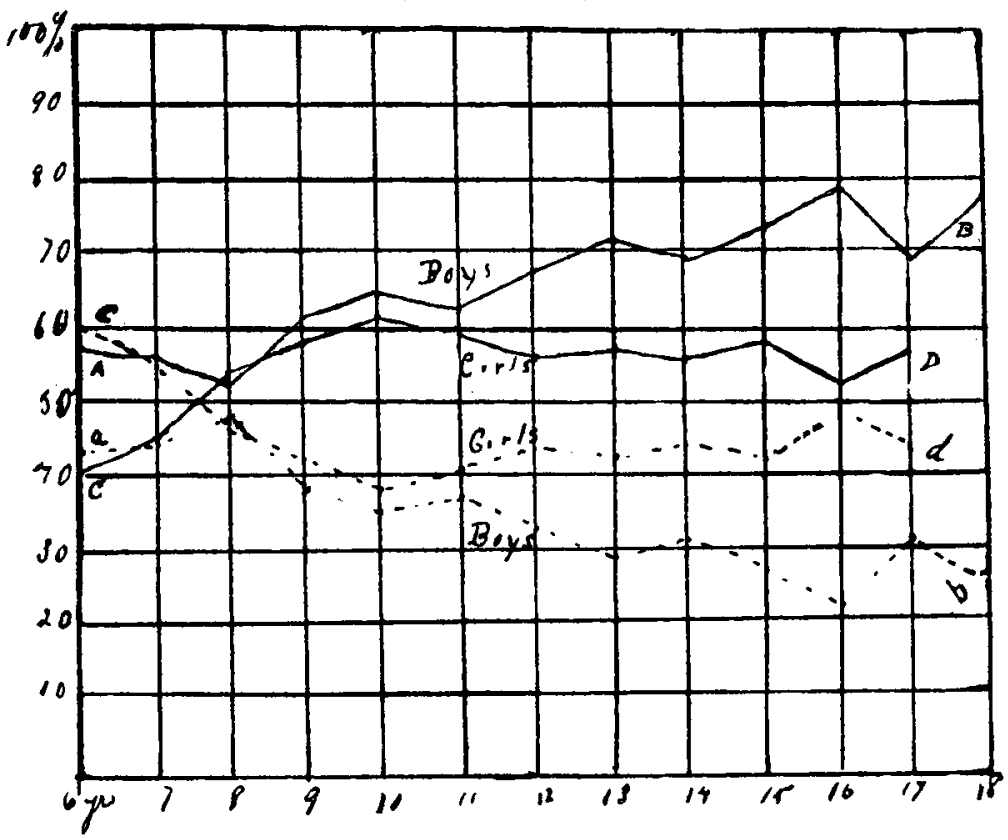


so prominent as to lead to the placing first among the prominent characteristics the desire for physical activity. Man has this in common with all animal life. The foregoing chart indicates relatively the strong ascendency of the physical exercises over all other forms of amusement; at every age after the ninth year it is represented as almost 2 to $\mathrm{I}$, and in the sixteenth year rising among the boys to 4 to $I$.

The proportion which those amusements tending chiefly toward physical development bear to all other amusements, is shown for each year from 6 to $\mathrm{I} 8$ by curves $A \mathrm{~B}$ and $\mathrm{C} D$. Curves $a b$ and $c d$ are the respective complements of $A, B$ and $\mathrm{C} \mathrm{D}$, and show the relative proportion of all other amusement.

From another standpoint the same characteristic is brought

The Twenty-Five Leadng Amusements.

Total, 1,000 Boys, 929 Girls.

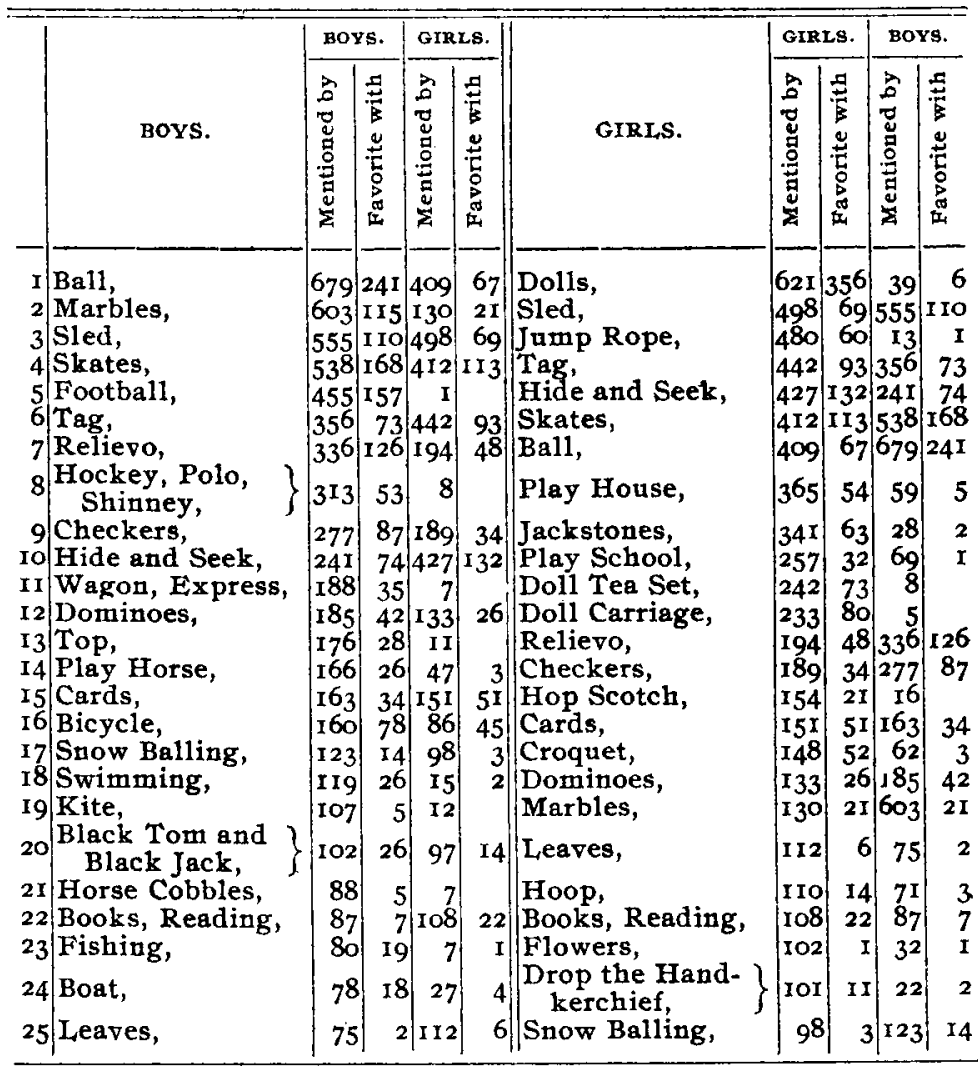


out in the Table of the Twenty-Five Leading Amusements (p. 226) 9 out of the first 10,17 out of the first 25 , and 39 out of the 50 amusements mentioned the greatest number of times by the boys, are from this class; while from among the girls 6 , I 5, and 32 amusements belong respectively to this class.

Closely associated with the pleasure in physical exercise pure and simple, is that in the development and exercise of skill. It enters nearly all competitive games, where the conscious desire of mastery is likely to be the strongest motive, as seen in the little girl of eleven who liked to play tag best because she could "run fastest." It is one of the most prominent features in many athletic exercises, as in walking stilts and skating; also in games requiring manual dexterity, as marbles, and ball; it appears as mental skill in cards and puzzles. Every child likes "to make something." The wise direction of this instinctive desire, to accomplish something and to receive credit for it, is one of the strongest motives to which a teacher can appeal in guiding a pupil:

\section{"With skill}

Goes love to show skill for the sake of skill."

Akin to this characteristic is the desire of emulation. Eight of the first 10 amusements of the boys, 15 of the first 25 , and 30 of the first 50 are of a distinctively competitive character.

If anything is needed to supplement general observation on the child's pleasure in the society of others, it will be enough for the present to call attention to the fact that many of the amusements and most of the games mentioned require the participation of several persons. This is particularly true of the common ring games, games of chase and parlor games, and of most dramatic games. The reader will recall from his own experience the increased pleasure derived from the bicycle when he is not compelled to ride alone. However, we shall see later on that this is not an essential characteristic of the child's amusements at all ages; in fact, that in his desire to satisfy his curiosity, or his desire to realize his mastery over some obstacle, or to create something, the child becomes oblivious to all except the immediate task before him. Hence there is a long list of toys and objects, used either as toys or other means of passing away time, where the social instinct seems entirely in abeyance. The toy makes for individual development, the game for social.

The love of dramatic expression is most marked in the many make-believe games, and in the traditional song games of early childhood; in many games of chase in which the children become bears, lions, Indians or policemen; in most toys, $e . g$., the doll and toy horse; in the animistic use of many objects, as flower babies, and pebbles used as animals. 


\section{EFFHCT OF AGE.}

Thus far the discussion has been of children en masse, with little distinction between the child of six and the young man of fifteen, and without regard to the different stages of development. Such treatment is almost inevitable in a study of this kind, but a few curves showing the general tendencies in children's amusements at different ages can be presented. Is there a play age? A time at which the child is more devoted to play than at any other age? The Curve of Interest in Traditional Amusements is a partial answer to this question.

Curve of Interest in Traditional Amusements.

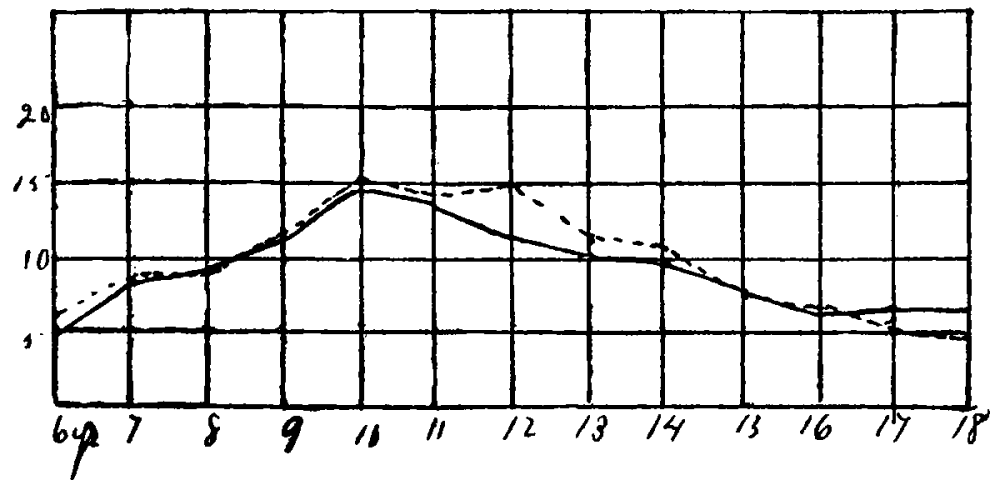

The basis of this curve is the average number of different amusements mentioned by the children at each age. Thus the children of six and seven mention on an average only five or six different amusements, but those of ten and eleven mention nearly fifteen. It is possible to give several interpretations of this. Were it not for the constant fall after the twelfth year, the form of the curve might be explained as due to increased facility of expression. There is still the possibility that the rise at nine and ten may in part be so explained, and the later fall may be due to the self-conscious restraint at the dawn of adolescence; but more probably it indicates, though somewhat vaguely, the period in which games predominate. From the eighth to the fourteenth year the average child knows more and plays more of the common traditional games than at any other period of life; and between ten and eleven interest in these is at its highest limit. Those who know from observation how fully the time of younger children is occupied with purely spontaneous play may at first question this curve. Let there be no misunderstanding; it does not say that the general play impulse culminates here, but that at this time the interest 
in traditional games is strongest. The curves for Relievo and Hide and Seek, characteristic games of this period, indicate more specifically the nature of these games and the relative

Curves for Relievo and Hide-and-Seek.

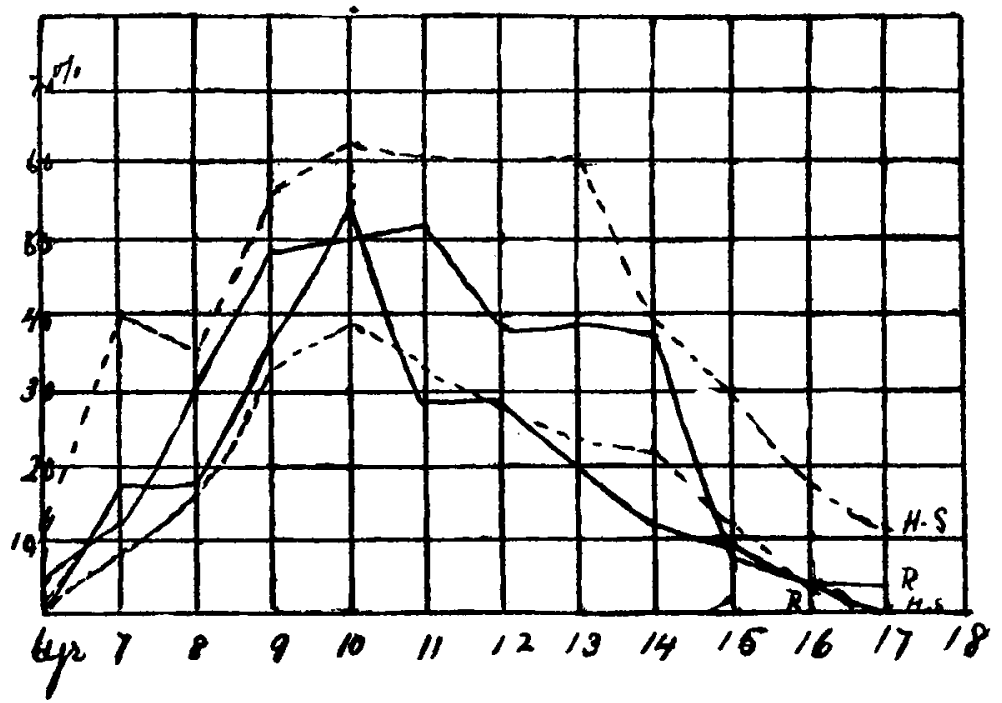

interest in them at different ages. Thus only eight per cent. of the boys of seven and eight years of age mention Hide and Seek, but fifty-five per cent. mention it in the tenth year.

A glance at the charts of Relative Interest at different ages will show in a general way that this is also the age at which different interests meet and blend; here for the last time the toy interest is considerable; it is the beginning of extreme interest in contests; it is the center of interest in games of chase.

The Curves of Relative Interest trace the growth of special interests, indicating the nascent periods in a number of groups. Thus the Curve of Games of Chase shows that ouly eleven per cent. of all the amusements mentioned by the boys of six years are of this character, but at nine years they amount to over nineteen per cent., and at sixteen they have fallen to less than four per cent. The particular toys and games included in the groups characterized by these curves may be learned by consulting the corresponding headings in the list of amusements already given. See pp. 217-222.

Three natural divisions in the school life of the child may be made in accordance with the relative predominance of different characteristics in his amusements. In the first period from the 
$33^{\circ}$ AMUSEMENTS OF WORCESTER SCHOOL CHILDREN.

Curves of Relative Interest.

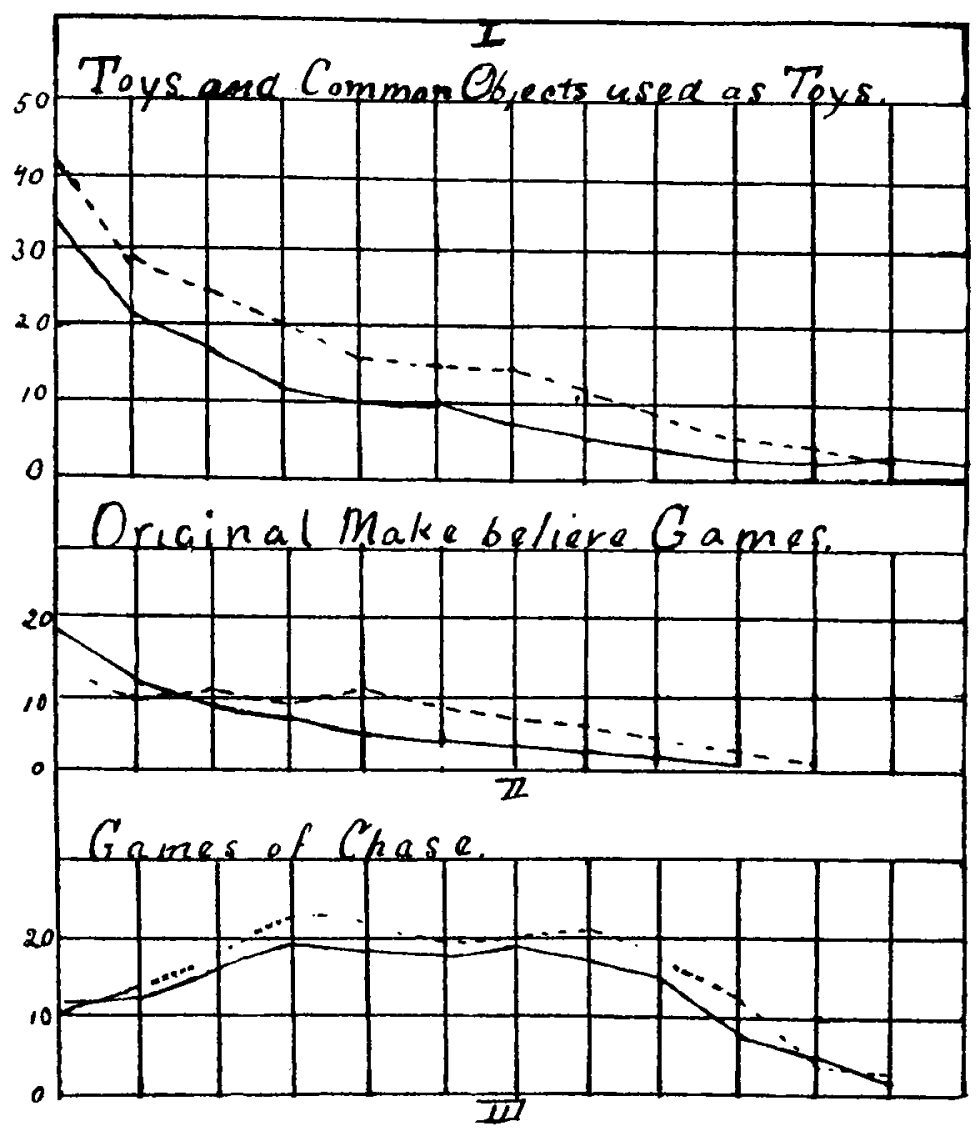

Ball Games.

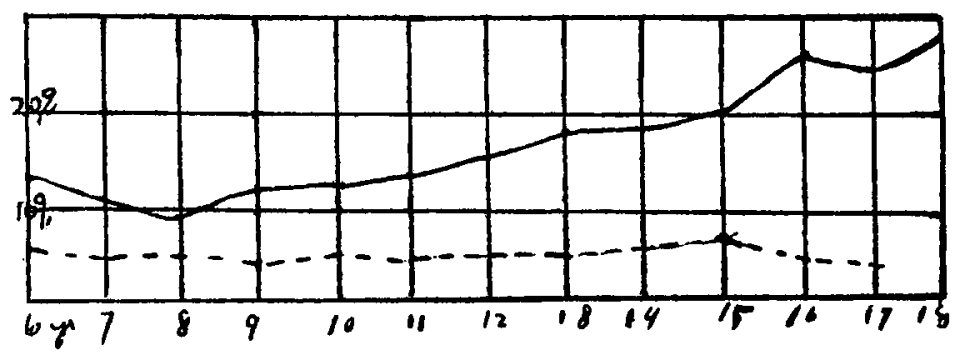


Card and Table Games.

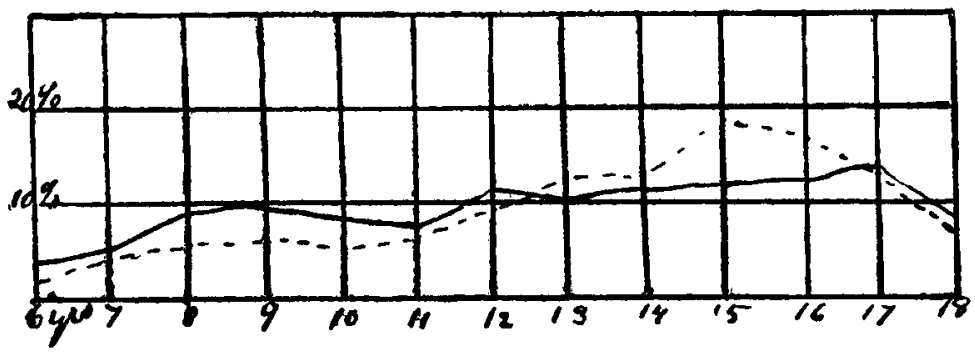

6th to the gth year, the greater part of the child's amusements center about some object, used symbolically or as a means through which to exercise the childish impulse for activity. In the second period, from 9 to I 3 years, the favorite amusement is some game calling for vigorous exercise of the whole body as seen in the curve of Games of Chase; though, as already said, it is also the period of the greatest diversity of interests. In the third period, from the I $4^{\text {th }}$ year onward, the creative spirit prevails - that spirit which compels the child to do something, to become something. Most of the amusements of this period are contests, and for the first time the co-operation of a number to secure a definite end, or promote a common cause, becomes a common characteristic; while the majority of the remaining amusements center about some result to be attained. ${ }^{1}$.

${ }^{1}$ Dr. Gulick: Some Psychical Aspects of Physical Exercise. Popular Science Monthly, Vol. L [I, pp. 793-808 (Oct.,'98). In this very careful study Dr. Gulick makes the five following divisions in the play life of the child :

I. Babyhood, $1-3$ years.

2. Early Childhood, 3-7 years.

3. Childhood, 7-12 years.

4. Early Adolescence, 12-r7 years.

5. Later Adolescence, I 7-23 years.

Of the first two periods he says: "Children before seven rarely play games spontaneously. They do sometimes under the stimulus of older children or adults." In the third period "these games are almost exclusively individualistic and competitive, forming a strong contrast with the games of early childhood." In the period of early adolescence " two elements predominate: ( $r$ ) That the plays are predominately team games, in which the individual is more or less sacrificed for the whole, in which there is obedience to a captain, in which there is co-operation among a number for a given end, in which play has a programme and an end. The second characteristic is, the period, with reference to its place, seems to be all of savage outdoor lifehunting, fishing, stealing, fighting, hero worship, adventure, love of 
In the period from 6 to Io years, and earlier, all manner of toys are used by the child in his amusements. Not only the toys which are bought or made for him, but every conceivable thing is utilized by him to give expression to his impressions of the world about him. Or perhaps one should say that, especially in the earlier part of this period, until about the ninth year, the toys and objects used form a means of comprehending; they are for the child organs of apperception; without the use of these crude symbols many of the simplest facts of life might never become a part of his earliest and most important stock of ideas experienced. The young child is a constant investigator of the phenomena about him, and is ever writing up the results of his empirical investigations in the language of his plays. The symbolic characters of this language may be a doll, a cart, a flower, a stick, a coal hod, a broom. Father's boots may be dear little babies, expressing all phases of early psychic life, and over which the young mother must exert a most watchful care, or they may typify a pair of prancing bays which attracted her attention earlier in the day. One young girl, beginning with her entrance into grade I, has continued to reproduce her school life by means of buttons through all the eight grades. In the buttons which represent the pupils she sees nearly the same children for each grade, but there is a new teacher each year. In such plays the imitation of the teacher is often reported to be almost perfect. It is a study in psychology, and from the child's standpoint might be termed adult study.

It has already been stated that the toy is a means of individual development. Does any one recall an active child who was ever content to remain long without some object in its hands?

With most of our kindergartens conducted on the principle of mutual co-operation, and in the face of the many facts showing that from earliest infancy the child delights in and craves the society of others, both of adults and children, but especial$1 y$ of others of its own age, it is rather venturesome even to suggest that this is not the period for extended co-operation.

animals, etc. This characterization obtains more with boys than with girls.". . . . .

"Comparing now the three major groups-early childhood, later childhood, and adolescence-it appears that the plays of early childhood are individualistic, non-competitive, and for the accomplishment and observation of objective results. The plays of later childhood are individualistic, competitive, involve active muscular co-ordination and sense judgment. The plays of adolescence are socialistic, demanding the heathen virtues of courage, endurance, self-control, bravery, loyalty, enthusiasm, and the savage occupations of hunting, fishing, swimming, rowing, sailing." 
However, the individual element is the prominent feature of the amusements of children until the eighth or ninth year, when for the first time those plays requiring the active co-operation of many individuals assume prominence.

The original dramatic games cannot well be classed as belonging to any one of the three periods mentioned, but rather form a connecting link between the first and second. If a function of the toys be to facilitate the apperception of one's more immediate sensuous environment, that of these games and of many of the dramatic games of tradition is to facilitate the assimilation of a class of ideas, wider in range and more imaginative; they lead the growing mind to new and rich fields. The catastrophe of London Bridge, and other traditional games, introducing titled personages, delight each new generation. Playing in an American city, the little Queen of France daily entertains the Queen of England or makes a royal visit to the court at Windsor. The broad range of this make-believe interest is probably between the years from 9 to 12 , yet within the narrower sphere of its immediate environment the younger child imitates to an equal extent. As Miss Frear has shown so clearly in charts II and III of her article on Imitation, in the early period the child imitates the "actual things," later the "idea." 1

The characteristic games of the second period call for vigorous physical exercise; thus the games of chase, in which running is the center of interest, formed twenty per cent. of all the amusements mentioned by these children between nine and twelve years of age. That this tendency to much exercise at this period has a very important relation to growth there can be no doubt. ${ }^{2}$ That the maximum of interest in such games corresponds to the lowest average in the tables of growth, as worked out by Kline and others, challenges the careful consideration of those competent to decide upon the effect of so much exercise at this period. "Increased action of the respiratory and circulatory systems is the most important physiological effects produced by muscular exercise." " This statement sums up about all that can be said at present of the effects of physical exercise. These effects, as worked out by Parkes, refer to the adult, and it is very probable that the results of this increased action, which would be injurious to an adult, might be beneficial if occurring in a growing child. Bierent* calls attention to the great increase in the volume of the heart

1 Ped. Sem., Vol. IV, p. 383 .

2 Ped. Sem., Vol. V, pp. 412-416.

Ralfe: Exercise and Training. N. Y., 1894. p. 30.

* Bierent: La Puberté chez l'bomme et chez la femme. Paris, I896. p. I6I. 
and in the richness of the contractile fibers of the heart at puberty, and to the fact that there is never, properly speaking, hypertrophy of the heart at this period; quoting Beauis, he also states that the heart beats at ten years number $9 \mathrm{I}$ per minute, and at fifteen years has fallen to 82. There is also a slight decrease in the normal number of respirations during these years. Thus this is the period of great development of the heart and respiratory organs, as well as the period of those activities which stimulate the heart to the greatest intensity; and yet apparently without the evil results certain to follow over-stimulation of the heart of the adult. We should have called this a period of violent exercise-and such its exercise most certainly would be for an adult, whose heart would soon be severely taxed were he to engage in some of the exciting games of tag common among boys at this age-had we not observed the promptness with which these boys respond to the feelings of fatigue. This instinctive knowledge of when he has had enough, and readiness to yield, is undoubtedly connected with that other virtue, here termed variety of interests, commonly called inattention. Combined, these are undoubted monitors of health and right development, guarding alike against excess in physical exercise and deteriorating monotony in school work. The person who attempts to get much physical labor from one of these boys discovers that he is lazy. The school teacher finds the grades in which boys of this age are most numerous, the most restless of all.

This period of extreme variety and vigor in physical exercise, and of rapidly flitting attention, is the period immediately following that at which the brain has ceased from its rapid early growth, having already by the eighth year reached its approximate limit of weight. ${ }^{1}$ During these years, according to the neurologists, the important phase in the development of the brain is the increase in association fibers and the further medulation of these fibers. This furnishes a plausible explanation of the function of these games and a reason for their diversity. May it not be that this great diversity of interests, this restless, roaming attention, this craving for something new, this extreme desire to be able to perform some special feat of skill-all of which are so strong at this period-may not this be Nature's way of guarding against a too early cramping of interest along few lines, her way of seeing that a broad general development is assured by providing numerous and varied experiences at this period of the development of association fibers? If this be Nature's plan, then it has been most severely sinned against by those who have prepared the courses of study in

${ }^{1}$ Donaldson: Growth of the Brain. N. Y., 1895, p. 107. 
our schools, for the fourth and fifth grades are the ones, beyond all other, most likely to be dry and uninteresting.

There is one other feature of this period which, although already mentioned, must not be left without special notice; it is the foundation for social co-operation, slowly laid by these games. Here are the beginnings of social life, of true citizenship, of combined independence and mutual dependence. In these varied games of chase, etc., are prominent those incentives to close attention, prompt and accurate action and selfcontrol to a marked degree. There, too, is the necessity of many taking part, and hence the frequent and often forced recognition of the rights of others, of a justice with hard and fast laws which may not be lightly disregarded. The constant bickering, the petty quarrels characteristic of the play of children from nine to twelve, trying parents almost to despair, and convincing disinterested persons that "such quarrelsome brats" must be beyond hope, are but the parliamentary debates of early legislators. As yet, however, there is no true social cooperation. There is little of the general combined action, definitely continued to attain a fixed end. Even those games in which an adult sees the possibility of great co-operative action are played by boys below the teens with little attention to the results to be obtained by combining efforts, but are studded with feats of individual prowess; every player strives to be the star. Yet in this struggle of individuals are conditions forcing mutual consideration and preparing for the more definite co-operation of later years.

Our curves show that as late as the ninth year nearly $20 \%$ of the amusements of these children was with common toys or with objects used as toys; that during the next four years about the same per cent. of running games occurred. The further characteristic of these earlier periods having been traced, a closing study of the third period is made. After the twelfth year the interest in ball games rises rapidly, from $15 \%$ at 12 years to $26 \%$ at 16 years; along with this grows a corresponding interest in cards. This statement means that a third or more of all the amusements of these boys just entering their teens, are games of contest-games in which the end is in one way or another to gain an advantage over one's fellow-in which the interest is in the struggle between peers. In foot-ball, for example, there can be no doubt of the pleasure derived from the physical activity which sends the blood coursing through one's veins, giving rise to feelings of a vigorous self, to a heightened consciousness of one's own powers; nor is this consciousness of power wanting in a game of cards; nevertheless it is the result to be attained, ever being attained as the contest proceeds, that centers the interest in the games. At this early 
stage in life the end must not be too far distant, the struggle must be ever present. Later on one may find delight in the severe preliminary practice which prepares him to win the later contest, or even in the strokes which are laying the foundation of his later success on the tennis court. Yet for the younger boy all this is drudgery unless the contest is ever present;-on the opposite side of the net must be some one to beat.

The beginnings and growth of this spirit of co-operation is beautifully shown by a comparison of the boys' curves for hide and seek and relievo (p. 229). The latter is played by two sides, and hence has slightly more of the features of co-operation, though in many respects the games are of a similar nature. Note the culminating point of the upward rise in each at about ten years, followed by the rapid decline of the first, and the continued interest in the second, due undoubtedly to the appeal to this growing delight in contest.

A look backward at the Curve of Interest (p. 228) gives an additional explanation of the downward drop after to. At ro years an average of 14 different amusements are mentioned; at 16 not half that number. This is the natural consequence from the class of games played; the more remote the end to be attained in a game, the more confined to it will be the attention, if any interest exists, and hence the exclusion of many games heretofore quite common. Thus certain games appear as powerful aids in the development of the ability to concentrate one's attention, to specialize.

\section{EFFECT OF Sex.}

The charts and curves have already brought out distinctions between the amusements of the sexes. A resume will make them clearer.

Nearly $40 \%$ of the 700 amusements of these children are common to both sexes, although about $30 \%$ are mentioned by each sex alone; for the most part the latter are games played but rarely.

A comparison of the leading games of the sexes calls attention to the greater variability of the male, a fact so frequently noted in the literature of evolution.

Amusements mentioned by fifty per cent. or more: Boys, Ball, Marbles, Sled, Skates ; Girls,-Dolls, Sled, Jumping Rope.

By $40 \%$ to $50 \%$ : Boys,-Football; Girls,-Tag, Hide-andSeek, Skates, Ball, Play House.

By $30 \%$ to $40 \%$ : Boys,-Tag, Relievo, Hockey; Girls,Jackstones.

By $20 \%$ to $30 \%$ : Boys,-Checkers, Hide-and-Seek; Girls, -Play Sol, Tea Set, Doll Carriage, Relievo. 
Thus only ro games are mentioned as commonly played by at least $20 \%$ of the boys, while among the same proportion of girls I 3 games are common. This difference is continued as other games are added, ro\% of the girls having 25 amusements in common, while the same number of boys have only 20 . This indicates that the girls have a larger repertoire of amusements that are used regularly. Although several of the groups of amusements which suggest in-door life, seem at first to indicate the opposite, a careful study of the data shows that the boys are less conventional. Thus the proportion of toys to other means of amusement is much smaller, especially after the ninth year, with the boys than with the girls, but the girls use very generally such toys as tea-sets and doll carriages, which together with dolls, aid their imagination in the reproduction of domestic life; while the boys, though they use no toys so generally, mention a greater variety. Again what is true of toys is also true of their imaginative games. A very large proportion of girls will play a few games dealing with local life, as playing house, or school, or playing parties; while fewer boys play any one game, but their games are more numerous and deal with a wider environment.

Forty per cent. of all the amusements mentioned were indulged in by both sexes. This element of common interest is seen in the general correspondence between the sex curves in the different charts. There are exceptions, however, as in the curve where the girls are made to appear to indulge in toys to a much greater extent than the boys, and in the curve of Ball Games which the reader might interpret as showing that the girls are lacking in the spirit of emulation. The first has already been explained as due to the doll interest, so predominant in girls. The second, though showing that the girls do not indulge to so great an extent in these contests of physical strength, does not negative the statement already made, that the third period for boys and girls alike, is marked by contests in amusements. The curve for cards clearly traces the growth of this element in the character of the girls. Still this spirit of stubborn contest, delights in the strife for mastery, is more characteristic among the boys, and is illustrated by the game of chess, and by the curves for Hide-and-Seek and Relievo (p. 229). Chess, a game requiring close application throughout, and attention from the start fixed on a definite end, is mentioned by twenty-five boys; but only one girl of nearly one thousand included it in her list. In comparing the curves just mentioned, it is found that the girls continue their interest in hide-and-seek, as they seem to in all distinctively running games, long after 


\section{$33^{8}$ AMUSEMENTS OF WORCESTER SCHOOL CHILDREN.}

that of the boys has been drafted off to more vigorous and general contests. ${ }^{1}$

Dr. Ellis in his extremely suggestive article on Dolls ${ }^{2}$ has clearly indicated their wide use and great value in the psychic development of the child. He also showed that doll playing was not confined to girls alone. But with him "dolls" had a much wider connotation than with these children who have listed "dolls" among their playthings. In the present study "dolls" must be considered as referring only to those toys commonly so called. Accordingly a very small proportion of the boys of school age are found acknowledging that they "play dolls," though the number reported is doubtless far too small, as there are obvious reasons why the average boy would not confess to this amusement. Many, however, speak of playing dolls at an earlier age, generally prior to their admission to school, when the doll was probably a common toy with them.

\section{EFFECT OF NATIONALITY.}

The child has the same general needs in his growth from whatever race he springs. On the whole, the following statement is true: the general character of the games played by these children of differing nationalities and diverse classes in society were the same whatever stage of their development was selected. This constantly recurring similarity was repeatedly brought to the attention of the writer during his work on the returns, and was to him an incontestable proof of the genuineness and accurateness of the answers.

The child, be he American, Swede, Irish, French or Jew, at the time when he enters school still clings to his toys; at nine, ten and eleven years of age he expands his chest, strengthens his heart, and gains a general control over the movements of his whole body, as he avoids capture or secures his prey in his games of chase. At the same time his active and unrestrained imagination will cause it to be more than a game of tag for him; he will be transformed for the time being into the character, human or animal, which the particular game calls for. The observer of the games at this period cannot fail to notice what a large proportion call for dramatization in some form. Later, whatever his nationality, the mere activity, the exercise in itself, will not be enough; at the end of it there must be something to show, some result, some object constantly in

${ }^{1}$ Groos states that those games in which is an active contest between sides, and necessarily a stricter subordination to law, are played more by the male sex; and he suggests that the social capacity of the American women is highly developed because they contest in all games freely with the boys.-Die Spiele der Menschen, p. 438 .

${ }_{2}^{2}$ Ped. Sem., Vol. IV, p. I29. 
view, else he considers his activity thrown away. Now is the time to interest him in something - to form permanent interests.

Emphasis has been properly placed upon this general correspondence; but on that account no one should think that there are not important differences, due at least to the traditional environment with which birth invests children, even if the difference be not rooted in the national character. The playthings and games of the parent are an important element in determining those of their children; and as promoters and transmitters of amusements the parents are second only to the children themselves. The returns as tabulated showed that fewer toys were mentioned by the Swedish children than by those of American parentage; and the writer was told by teachers acquainted with both Swedish and American homes that fewer toys are found in the former than in the latter, this difference being very noticeable. A singular case in point is found in the returns under the heading of "Cards." In one school where there were 237 girls, for the most part of American parentage, 48 reported that they played cards, and 18 of these, an unusually large proportion, reported "Cards" as a favorite; but in two other schools in which the great majority were Swedish, although the total number of girls was 287 , only two mentioned cards, and these two were Irish. The returns, however, indicate that the Swedish children more often made toys for their own use than did the American; whence it may be inferred that paucity of toys in the Swedish home is due more to parental custom than to childish instinct. The returns also showed that the Swedish children indulged in the games calling for active physical exercise to a much greater extent than any of the other nationalities represented, though the environment of Worcester children encourages games of this character, and their proportion relative to other amusements is very large among all classes of children in this city. This characteristic is prominent among the games of the Swedish girls as well as boys; with them running games of all kinds, skating and "sliding" are prime favorites. This great enjoyment of physical activity accords well with the usually accepted characteristics of northern races, and especially of the Scandinavian in its own peninstular.

$I$ have to thank Miss Foley, the superintendent of physical culture in the city schools, for one fact of great interest. At the time these data were being gathered, she was conducting the very practical experiment of introducing common games into some of these same schools in the place of the ordinary physical exercises. In the course of her experiment she found that the same games were not equally successful in all schools; and that in one school, in which the children were largely of 
American parentage, the spirit of rivalry, an oppportunity to beat, was necessary to the successful introduction of any game. This spirit of rivalry is characteristic of cards, just mentioned as an example of a distinction between American and Swedish games; and in all games of this class the distinction holds good between the nationalities;--more rivalry among the Americans, among the Swedes more vigorous physical exercise.

\section{EFFECT OF Locality and Season.}

Comparing the tables of the leading amusements in Worcester (p. 226) and Brooklyn (pp. 240-242), and of leading toys in Westfield, a general agreement is found in the order and relative percentage of similar games; thus with the boys ball is first in both the former places, and sledding and skating are third and fourth respectively, while checkers is ninth on all three lists; the sled also is second with the girls from the first two places, and checkers occupy the fourteenth position.

On the other hand hockey (shinney) stands much higher on the Worcester list, and relievo is not found at all among the leading games ${ }^{1}$ of Brooklyn boys, though extremely popular in the former city. Also the list from the Brooklyn girls give us a surprise as we read "dolls" down into the fifth place, jump rope, sled, skates and jackstones preceding, nor do games of chase appear to be so great favorites, and cards are played more. These are, as will be seen, only typical differences, such as will be found on comparing any two localities, and they illustrate two things which largely determine the free amusements of any community: (I) the effect of tradition, (2) and that of physical environment.

\section{LEADING AMUSEMENTS.} Boys.-Brooklyn. Total number, 205.

$\begin{array}{cc}\text { Mentioned by } & \text { Favorite with } \\ \text { I5I } & 68 \\ \text { IOI } & 53 \\ \text { I09 } & 15 \\ \text { I00 } & 9 \\ 89 & 17 \\ 73 & 16 \\ 64 & 7 \\ 51 & 5 \\ 48 & 5\end{array}$

1 "Ring Relievo," however, is mentioned and described by Stuart Culin in the Street Games of Boys in Brooklyn, N.Y. (See Journal of American Folklore, Vol. IV, pp. 221-237.) This is the same game, although not played exactly as it is by the boys in Worcester. 
AMUSEMENTS OF WORCESTIR SCHOOL CHILDREN. 34I

$$
\text { Boys.-Brooklyn.-Continued. }
$$

Meutioned by Favorite with

9. Checkers,

ro. Pass Walk,

Ir. Hide-and-Seek,

12. Sleigh Riding,

13. Prisoner's Base,

14. Snap the Whip,

15. Swimming,

I6. Dominoes,

I7. Puss-in-the-Corner,

18. Play Horse,

19. Bicycle and Velocipede,

20. Lotto,

21. Wagon,

22. Kick the Can,

23. Kites,

24. Shinney,

25. Messenger Boy,
45

40

39

37

36

33

28

27

27

24

23

22

20

19

I9

18

17
15

5

5

5

2

I

9

2

I

6

6

4

4

2

o

o

8

All of these boys were between 8 and 16 years old, the great majority between ro and $I 5$.

LEADING AMUSEMENTS.

Girls.-Brooklyn. Total number, 223.

I. Jump Rope,

2. Sled,

3. Skates,

4. Jackstones,

5. Dolls,

6. Tag,

7. Play House,

8. Hide-and-Seek,

9. Bicycle and Tricycle,

ro. Roller Skates,

I 1. Play School,

I2. Dominoes,

13. Doll Carriage,

I4. Checkers,

15. Ball,

I6. Lotto,

I7. Reading and Books,

I8. Parchesi,

19. Sewing,

20. Croquet,

21. Messenger Boy,
Mentioned by Favorite with

I 50

I3I

123

I 2 I

I 7

82

79

67

$5^{8}$

8 I

50

49

48

47

46

46

45

42

36

33

31
39

14

27

33

60

12

22

I9

25

I 5

I 5

I 5

I 7

7

9

7

3

Io

3

I I

6 


\section{Girls.-Brooklyn.-Continued.}

22. Old Maids,

23. Sleigh Riding,

24. Bean Bag,

25. Play Store,
Mentioned by

$\begin{array}{ll}25 & 2 \\ 23 & 2 \\ 21 & 0 \\ 19 & 1\end{array}$

These girls were between 9 and 16 years of age, the majority between Io and 13 .

TyE Favorite Toys.

Boys.-Westfield, Mass.

Total, 701. $295880 \quad 77 \quad 118 \quad 118 \quad 102$ 90 $34 \quad 15$ $\begin{array}{llllllllll}\dot{8} 7 & 8 & 9 & 10 & 11 & 12 & 13 & 14 & 15 & 16\end{array}$

I. Top, $\begin{array}{lllllllllll}297 & 12 & 20 & 26 & 30 & 56 & 53 & 38 & 39 & 18 & 5\end{array}$

2. Ball, $\begin{array}{lllllllllll}260 & 7 & 15 & 29 & 20 & 46 & 44 & 48 & 31 & 13 & 7\end{array}$

3. Marbles, $\begin{array}{lllllllllll}227 & 4 & 10 & 15 & 20 & 45 & 43 & 39 & 34 & 13 & 4\end{array}$

4. Wagon, Exp'ss, $150 \quad 8 \begin{array}{llllllllll}12 & 20 & 24 & 32 & 21 & 22 & 7 & 2 & 2\end{array}$

$\begin{array}{llllllllllll}5 . & \text { Football, II } & \text { I } & 3 & \text { 10 } & \text { II } & \text { 15 } & 27 & 22 & \text { I } 7 & 7 & \text { I }\end{array}$

6. Bicycle,

$\begin{array}{lllllllllll}95 & 3 & 5 & 4 & 7 & 17 & 22 & 17 & 12 & 7 & 1\end{array}$

7. Drum,

8. Skates,

9. Checkers,

$\begin{array}{lllllllllll}84 & 4 & 8 & 8 & \text { II } & \text { I8 } & \text { I6 } & 8 & 8 & \text { I } & 2\end{array}$

ro. Gun,

I I. Cars, Engine, $\begin{array}{llllllllll}76 & \text { I } & 2 & \text { II } & 4 & 16 & 18 & 13 & 9 & 2\end{array}$ $\begin{array}{llllllllllll}75 & 1 & 2 & 6 & 5 & 10 & 16 & 7 & 12 & 15 & 1\end{array}$

I2. Sled, $\begin{array}{lllllllllll}74 & 1 & 2 & 6 & 3 & 19 & 16 & 17 & 7 & 2 & 1\end{array}$

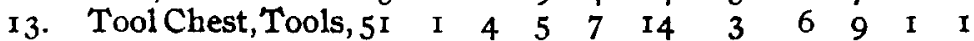

15. Bat,

I6. Boats (toy), 49

17. Horse (toy), $\begin{array}{llll}1 & 4 & 6 & 13\end{array}$ 8 10 320 2

I8. Books,

19. Cards,

20. Blocks,

2x. Kite,

22. House,

23. Dominoes,

24. Dog,

25. Puzzles,

$\begin{array}{lllllllllll}48 & \text { I } & 4 & 5 & 7 & \text { I } 4 & 3 & 6 & 9 & \text { I } & \text { I }\end{array}$
$\begin{array}{llllllll}45 & 6 & 2 & 13 & 7 & 6 & 7 & 4\end{array}$ $\begin{array}{lllllllllll}34 & 2 & 0 & 4 & 5 & 8 & 7 & 3 & 3 & 1 & 1\end{array}$

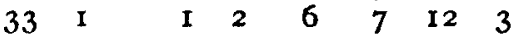
$\begin{array}{lllllllll}3 \text { I } & \text { I } & 5 & 3 & 4 & 3 & 3 & 7 & 5\end{array}$

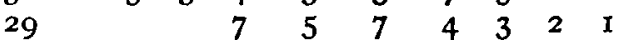
$\begin{array}{lllllllllll}27 & 2 & 5 & 3 & 2 & 3 & \text { I } & 4 & 4 & 2 & \text { I }\end{array}$ $\begin{array}{llllllll}24 & 3 & 4 & 2 & 3 & 5 & 4 & 3\end{array}$ $\begin{array}{lllllllll}24 & 2 & 3 & 3 & 3 & 3 & 4 & 4 & 2\end{array}$ 23

The Favorite Toys.

Girls.-Westfield, Mass.

Total, 808. $3565 \quad 102$ 108 $104 \quad$ I2I $128 \quad 1002419$

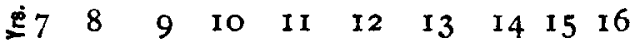
$\begin{array}{llllllllllll}\text { I. Dolls, } & 626 & 30 & 61 & 97 & 98 & 90 & 102 & 92 & 44 & 6 & 4\end{array}$

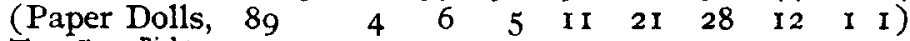

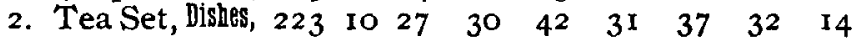




$$
\text { Girls.-Westfield, Mass.-Continued. }
$$

Mentioned by Favorite with

3. Doll Carriage, I $8 \mathrm{I}$

4. Books,

I34

5. Top,

125

6. Ball,

II9

7. Bicycle,

8. Sled,

69

9. Jump Rope,

69

Io. Skates,

68

Ir. Piano,

67

1 2. Checkers,

13. Hoop,

14. Stove,

15. Paint,

16. Blackboard,

62

17. Dominoes,

18. Doll's Bed,

57

49

49

45

43

39

19. " Table, 37

37

20. " Chairs, ttc.,33

$\begin{array}{llllllll}5 & 18 & 27 & 34 & 36 & 24 & 31 & 7\end{array}$

$\begin{array}{lll}4 & 7 & 17\end{array}$

5 10 22

24

I 7

27

2117

$\begin{array}{lll}12 & 3 & 2\end{array}$

21. " Cradle, 29

22. Blocks,

23. Cards,

$$
29
$$

24. Play School, 25

25. "House, 24 IO 1

I7

19 1

$\begin{array}{lll}15 & 2\end{array}$

$\begin{array}{llll}21 & 17 & 26 & 16\end{array}$

37

$\begin{array}{ll}2 & 15 \\ 5 & 17\end{array}$

8 II

9

$\begin{array}{lll}12 & 15 & 14\end{array}$

I I I 4 I I

I0 14 II 1

23

$4 \quad 17$

2

7 10 14

6

1415

4

8
I I

I

$\begin{array}{llll}3 & 20 & 7 & 5\end{array}$

We have seen how parental influence was still a factor in determining the plays of the Swedish children of Worcester; here again is a most striking instance of a game, "relievo," nourished and developed until it is mentioned by a third of all the Worcester boys, and yet apparently played but little by the boys of Brooklyn, a little more than one hundred miles distant. But the interesting feature of it all is the substitution of games of the same class. In Brooklyn, Pass Walk and Prisoner's Base appear to be the substitutes for relievo, while general observation in Chicago and vicinity puts "Pomp, pomp, pull away" in its place.

One reason why shinney is three times as popular in Worcester as in Brooklyn, and that running games of all kinds appear to be more popular, is undoubtedly the exceptional inducements offered by the physical conditions of the former city; the many small ponds suitable for shinney are a constant invitation to the small boy with a pair of skates, and the innumerable vacant lots, covered with grass, - not yet the dirty dumping places so common in large cities, - have furnished Worcester, free of charge, an excellent system of small parks 
for playgrounds. ${ }^{I}$ The only regretable fact is that these are neither as frequent nor as grassy in the poorer neighborhoods, where exist the greatest need of them, and that they cannot be made permanent. These back lots and the broad, shady streets offer the choicest opportunity for indulging in running games of all kinds.

While tradition and environment may perhaps have helped to plaec two amusements, jumping rope and jackstones, always favorites with city girls, higher up in the Brooklyn list, one other factor not due to locality has had its influence on the relative position of "dolls" and "cards;" a large proportion of the Brooklyn girls were in the upper limit of "the doll age," or, speaking from the other standpoint, they were just entering "the age of card interest." Had equal numbers of the same age been taken, the similarity between the two lists would have been much closer.

The difference in the Westfield list is due in the main to the fact that it covers less ground than the others, being devoted to toys alone and giving greater emphasis to these. Hence are placed high on this list toys which are not found at all in the other two. Another reason why certain of these toys, as wagons, cars, and drums, occupy so high a position, is found in the relatively greater proportion of children below ten years of age. The very prominent position of the top amoug Westfield toys may be due to either of two causes: it may be one of those local toys which has become strongly rooted there, or the returns may have been taken when "tops were in." Probably both of these conditions existed, for the top has a very wide range in its relative popularity in different localities, and, like marbles, it comes and goes like an epidemic.

The returns from our syllabus give very general or indirect answers in regard to the influence of the seasons in determining the games played; but a few observations are perhaps worth recording. In notes taken by the writer in Chicago during the spring of 1898 the following occurs: "Sat., Mar. 6." Went-

${ }^{1} \mathrm{G}$. M. West, in his article upon The Anthropology of American School Children, found in the proceedings of the International Congress of Anthropology, Chicago, 1894, makes the following statement, which is of suggestive interest in this connection: "The Worcester childreu are markedly above the average in stature, while the Toronto and Boston children are almost as markedly at the opposite extreme."

${ }^{2}$ On the I5th of February, I899, the writer saw, for the first time of the season in Chicago, marbles, ball, and various tag games, but the conditions were peculiar; for fully a month the weather had been exceediugly cold, the thermometer frequently registering $15^{\circ}$ or more below zero, and there was little or no snow on the ground. Suddenly, within twenty-four hours, there was a rise of about $70^{\circ}$. After a few days the temperature again dropped, and these games disappeared from the streets as suddenly as they came. 
worth Avenue electric. Saw, for the first time of the season, marbles, jackstones, and jumping rope. Time, late in the afternoon; weather, mild and fair. During the next week all these games, together with ball, became common on the Normal campus." "Mar. 3I. I.00-2.00 P. M. Cloudy and cold. During a walk of several miles I saw many groups of small boys without seemingly anything to do-just loafing along, or sitting with hands in pockets. Not a game of marbles, only two of ball, and a few of jump rope." By the last of April of this same year the boys of this vicinity had nearly stopped playing marbles, though a few sporadic games were detected during the next month. Ball was the prevailing game, though games of chase and similar running games began to be frequent, especially in the dusk of evening. General observations, made both in Chicago and Worcester, place the greatest interest in running games during the months of May and June, and the hours of the day those immediately following supper. While these are approximately the correct dates for a few games at a given latitude, it by no means follows that they would be correct for other localities. Indeed, we are told that the Greek boys of the present day play ball in winter instead of summer, and local conditions will undoubtedly modify the time of most games.

It is difficult to determine the time of playing; to give the reason is still more difficult. One young boy, when asked how they happened to begin to play marbles during a certain term, replied: "Oh, first one of the boys brought some marbles to school, and then others brought theirs." This does not explain how the first boy happened to bring his marbles, but under favorable conditions it is easily seen how a game may rapidly spread by imitation over a whole neighborhood, or even a city. In the varying environment furnished by the seasons are found most favorable settings for the games when they are played; in the fall when the body requires a high physical tone to withstand the inclemency of the season, the favorite out-of-door amusements are those which contribute to the formation and maintenance of this tone; the long winter evenings contribute their share to the mental growth in another but milder manner. In summer the favorites are out-door activities, but they do not make so continuous and severe demands on the physical powers. In the spring, when the bright, warm sun, and fresh, fragrant air calls children out of doors, but the deep sticky mud draws limits about their feet, the small spongy patches of fresh earth stimulate with irresistible strength the boys' associations with marbles, the girls with the jumping rope. And thus undoubtedly can the periodic vogue of many of the recurring games be explained on the basis of natural associations, quickened 


\section{AMUSEMENTS OF WORCESTER SCHOOL CHILDREN.}

by the physical phenomena of each season; and once started at a favorable time a game spreads by imitation.

EFFECT OF NUMBER OF COMPANIONS AND OF TIME OF PLAYING.

A few facts dealing with the problems of companionship, and with the effects of Sunday and evening restraint, have been gathered from the returns of these school children, and are here presented. ${ }^{1}$

Boys. Girls.

1000929 Total number.

\section{When Alone.}

$340 \quad 325$ Books, reading. (Especially from 12 years on.)

38 II7 Music. (Instrumental and vocal, principally the piano.)

5355 Drawing, Painting, etc.

$21 \quad 81$ Making something.

- 74 Dolls.

3I $\quad 5^{2}$ Make-believe Games. (Especially at early age.)

20 o Marbles.

I 83 Ball.

7 I Walks.

45 Cards.

24 Talk. (To one's self, to Kitty, etc.)

II. When in Groups of Two or Three.

40 I5 Make-believe Game.

I 876 Games of Chase.

8I I Io Talk, Tell Stories, Riddles, etc.

$98 \quad 7$ I Cards, Checkers, etc.

I 64 Music. (Instrumental and vocal, mostly singing.)

66 o Marbles.

334 Ball.

$3 \quad 3$ Make something.

IO 8 Walks.

27 Drawing, Painting, etc.

o 24 Dolls.

825 Reading. (Includes also several cases of more than three.)

${ }^{1}$ Data regarding the amusements of younger children at different periods of the day, have already been secured through the extreme kindness of friends and of those interested in child study; and these, although not yet carefully studied, reveal many interesting points, which may form the basis of a later article. 
III. When in Groups of More than Three.

$269 \quad$ I96 Games of Chase.

37 I04 Make-believe Games.

$37 \quad 43$ Cards, etc.

$27 \quad 73$ Talk, Tell Stories, Riddles, etc.

674 Ball.

$4 \quad 33$ Music. (Principally singing.)

I3 O Marbles.

94 Walks.

06 Dolls.

IV. Sunday Amusements.

203
64
48
52
9
6
14
0
15
12
1
3

246 Reading.

80 Games of Chase.

65 Walks.

38 Cards. (Includes Bible Games, etc.)

53 Music. (Instrumental and vocal.)

34 Make-believe Games.

I3 Drawing and Writing.

I5 Dolls.

- Marbles.

2 Ball.

1o Make something.

3 Talk, Tell Stories.

V. Evening Amusements.

102280 Reading.

6643 Cards.

4429 Drawing, Painting.

1350 Music. (Instrumental and vocal.)

$4 \quad 37 \quad$ Make something.

269 Games of Chase.

I 20 Make-believe Games.

95 Walk.

5 O Marbles.

24 Ball.

4 I Talk, Tell Stories.

The list of amusements "when alone" must have impressed the reader with the great emphasis given to the activities dealing with associative and constructive imagination; reading, music, drawing, making something, dolls, and make-believe games, - such is the order. Here is the suggestion of restless activity and of the paths along which it is expressed; under these conditions the creative power of the child is most active. Yet the one thing overcapping all others is the reading habit, especially strong after the twelfth year. Is this overwhelming 
tendency to seek amusement in reading a perfectly natural one, or is it simply the most convenient form because open to all? Would other activities take its place, had earlier training qualified more persons to indulge in them ? It seems probable that the latter is the truer answer; and had educators recognized the importance of leisure and its activities in the formation of each individual, our schools would strive to develop in each pupil the ability to do something besides gulp down stories. In his admirable monograph on reading, Dr. Hall has shown the abuse of the ability to read when it degenerates into a mere form of amusement; ${ }^{1}$ and in later lectures and addresses he has made a strong plea for the acquisition by each child of the ability to do as many different things as possible. "How many things do you know how to do?" is his question. This plea has been made on the psychological ground that motor activity is a means of brain development. Surely, then, if the acquisition of these different powers tend to a more evenly balanced development of a man mentally, the continued practice of such activities must tend to steady one throughout life.

Lists II and III are characterized by those amusements which more than others foster the development of social habits -habits of forbearance, obedience to law, competition, cooperation, public spirit. The fancy of each child now is less free than in the condition of list I; even in the make-believe games it must yield to that of others, become more conventional and more cramped. List II by itself emphasizes the value of a chum in the normal development of every individual. If a child has not, in brother or sister, one of its own age with whom the most confidential relations may be established, it is the duty of parents to encourage and promote such relations.

The Sunday and Evening amusements exhibit the effects of restraint in two ways: first, in the predominance of isolating amusements, - a glance will show how much more these groups

1 "Reading, in emancipating men from their physical and mental environment, often weakens local pride and local interest, and creates a distaste for what is nearest, and what, therefore, should be pedagogically first. Finally, we sometimes find a habit of passionate reading in children that not only interferes with physical development, but destroys mental and moral independence, and may be called as morbid as the writing mania. Thus I have graduslly almost come to the opinion that many of our youth would develop into better bealth and stauncher virtue, and possibly better citizenship, and a culture in every way more pedagogical and solid, had they never been taught to read, but some useful handicraft, and the habit of utilizing all the methods of oral education within reach, instead." Hall, G. Stanley : How to Teach Reading, p. I7. 
resemble group I than either II or III; and secondly, in the character of certain amusements which appear as a sort of protest against this restraint. As if the child should say: "If there 's nothing else I can do in peace, I 'll read ;" or "I 'm tired of staying in all day. Let 's take a walk." Here is a basis for the consideration of the problem which confronts so many conscientious mothers and fathers: "What shall we do with our children Sundays? Shall they play the same games as on other days?" The answer in the individual case will depend much upon the personal belief and Sunday habits of the parents, but should be modified by the consideration of the probable effect of the day's activity upon the child.

Can one day in seven be made to have a different signification from other days without an injurious influence upon the young through the associations they form about it?

Something can be said for the educational value of a rigid Sabbath. If, even by what seems an artificial restraint, we are led to habits of contemplating the deeper and more spiritual things of life, to a more careful consideration of our duties toward God and man, the value of these habits from the commonly accepted moral standpoint cannot be denied; and if at the same time the American people learn how to rest from their nerve-destroying restlessness and activity, the value of a Sunday different from other days will be equally apparent from the physiological standpoint. But if a difference is to be made, the effect of the change should be the criterion of its legitimacy. It is our belief that psychology and physiology both advocate a holy day of rest, and that if parents felt the need of such a day, and its import, the character of the day would seldom appear so irksome to the child; for his appreciation of the day would be greater, and his liberties wider.

\section{ARTICLAS MADE OR ATTEMPTED.}

Although question $\mathrm{V}$ asks the pupils to "describe any plaything" they had made, it is surprising to find so few games have been made; a few puzzles and checker boards are about all. There are, however, a large number of toys which are miniature copies of things in the child's environment, and which form the material basis of many of his plays; there are the dolls and toy animals, the houses, the water wheels and other machines, the sleds, boats, carts, the wooden axes and other model tools, the sword and gun. These are the things most commonly made by children; and they touch human life on all sides. Of the toys made, not included in this class, the majority are those that develop skill and self-mastery on the part of the user; the ball, top, stilts, snowshoes, and many kinds of gymnastic apparatus belong to this class. 
As the children approach the "teens" a tendency arises, that is well expressed by one of the girls, who no longer makes playthings, but " things that are useful." Under this class are included the articles for Decoration as well as for Use; things for personal adornment, to beautify the school or home, and even various foods. This whole list, as may be seen, by no means begins to reach the limit of what the child may make, though it is suggestive both to the framer of a course in manual training and to a teacher looking for suggestions for her daily work. $^{1}$

\section{For Play.}

\section{Games.}

By Boys:-Puzzles 14, Marble game I.

By Girls:-Puzzles 4, Anagrams I, Checkers I, "Game similar to checkers" I, Old Maids (cut from paper) I, Dominoes $x$.

\section{Dolls and Doll Toys.}

By Boys:-Dolls 31, Man 7, Soldier 4, Indian I. (Material used, paper, wood, clothes pins, and potatoes). Jumping Jack 4 , Clothes pin Fighter 2, Hat I, Boot I, Doll Furniture 53, (chairs, tables, beds, benches, cradles, swings, cupboards, dishes. Material, paper, pasteboard, wood, clay.)

By Girls:-Dolls 304. (Materials, rags, paper, wood, clothes pin, pipe, stick, peanuts). Jumping Jack 3, Doll's Clothing 252 (dress, apron, waist, cap, bonnet, hat, cape, skirt, petticoat, cloak, pocket in dress, quilt, shoes, slippers, bloomers, doll's outfit). Doll's Furniture r4I. (Bed, chair, rocking chair, high chair, sofa, table, dishes, carriage, cradle, bureau, hammock, pillow, mattress, stove, candlestick, tin looking-glass, wooden tub, benches, rope, knives and forks. Material, paper, wood, pasteboard, clay, burdocks.)

\section{Toy Animals.}

By Boys:-Horse 12, cat 9, Snake 3, Animals 2, Dog, Elephant, Fox,

${ }^{1}$ Mr. James P. Upham, who for over twenty-five years has been connected with the premium department of The Youth's Companion, states that for prizes the boys are most likely to choose "something they can make something or do something with, or to earn something with;" thus the ecroll saw has been by far the most successful premium ever offered by the paper; likewise the most popular premium for girls has been the Kensington Patterns (for art work). The following list includes the most popular premiums as determined during a period of twenty to thirty years: The camera (at present), microscopes and telescopes, magic lanterns, soldering casket, glass cutter, pocket tool-holder, outfit for making initial jewelry, carving tools, pocket knives, materials for building canoes, Florentine Bent Iron Work, Weeden's Engine, materials for a model motor, toilet hair clippers, oil painting outfit, water colors, etc., celluloid decorating outfit, dolls, collection of puzzles, megaphone, printing press, and certain books. In general, "educative" toys were considered unsuccessful as premiums, as also were electric toys on the whole. The latter were not nearly as popular as steam toys. 
Goat, Monkey, Owl, Oxen, one each. Material, wood, paper, pasteboard and potatoes.

By Girls:-Cat 7, Horse 6, Sheep 3, Baboon 3, Rat 2, Dog 2, Duck 2, Bird, Clay Animals, Cow, Fish, Oxen, Pig and Tiger, one each. Material, paper, rags, cloth, wood, handkerchiefs, pussy willows, and potatoes.

\section{Model Toys.}

By Boys:-House, Tent I25, Snow Fort 8, Lighthouse 2, Bridge, Church, Depot, Sew Mill, and Small Farm, one each, Cart 3 $_{38}$, Whip 5, Reins 5, Harness 3, Gig 3, Coasting Cart I, Sail for coasting cart 1 , Goat Harness I, Bicycle 6, Engine, Cars, etc., 9, Railroad Track 4. Boats 205, includes toy boats of all kinds, birch bark canoes, used for models, and also raft and boats for áctual use made or attempted by boys in their terms. Sled $\mathrm{I}_{5} \mathrm{I}$. The returns did not always distinguish the toy sleds from those made for use. Toboggan 6, Sleigh I, Sledge 1, Ladder 30, Axe and Hatchet 15, Fork 9, Knife and Fork I, Shovel 7, Snow Shovel 3, Circle Saw 6, Hammer (wood) 3, Spoons 2, Rake 2, Spade I, Billy I, Acorn Pipes 18, Cob Pipes 8, Orange Skin Teeth 4, Clock 2, Wire Spectacles I, Money I, Sword 66, Knife 47, Gun and Pistol 28, Bow and Arrow 16, Bow Gun 3, Soldier's Hat 10, Cannon 4, Spear 3, Tomahawk 2, Drum, Fife, Flag, Lariat, Marble Gun, and Shield, one each.

By Girls:-House, tent 68, Snow House 4, Log Cabin I, Hut I, ighthouse 2, Toothpick House I, Doll Park I, Bank I, Cart 9, Reins 7. Harness I, Engine I, Boat 58, Sleds 21, Ladder 2, Saw, Rake, Spoon, Tin Scissors I each, Clock 3, Eye Glasses 3, Pipe I, Knife ro, Sword 4, Gun I. The material used by boys was commonly wood, by girls paper.

\section{Mechanical Toys.}

By Boys:-Water Wheel and Water Hanmer 20, Sand Wheel 2, Trip Hammer I, Derrick 9, Scales 9, Theater 8, Elevator 5, Machines 4, Shafting I, Shaft-holder I, Train signal switches, etc., I, Piece of tin with two holes through which passes a string; pull the string and it will cut Io, Kite 39, Pin Wheel, Windmill (wood) 3, Balloon 9, Air Ship I, Electrical Apparatus I, Batteries ro, Motor 7, Dynamo, Electric Car, Holtz Machine, Induction Coil, Incandescent Light, Switch Board, Telegraph, one each, Telephone 16, Camera 5. Sketching Camera I, Magic Lantern, Jack Lantern 21, Sling Shot I6, "Stopple," feather dart 12, Tic Tac I1, Pop Gun 2, Force Pump 2, Pea Shooter I, Traps I 2, Fish-rods 3, Fish-lines $x$, Whistles 26, Clappers 8, Violin 2, Banjo 2, Drumstick I, Wooden Drum to use in school $I$.

By Girls:-Scales 4, String through button or tin cover - twist thread and then pull it $x$, Kite I2, Pin Wheel 7 , Windmill (paper) 3 , Telephone 6, Feather Dart I, Cat's Rattle I, Horn 2, Accordion, Guitar, Violfn, ore each.

\section{Toys for Physical Exercise.}

By Boys:-Ball 42, covering a ball was too difficult for one boy of fifteen, Top 26, Marbles (clay) ro, Bat 7, Foot-ball 3, Horse Shoe Rings 5, Bean Bag 1, Boomerang I, Bowling Alley I, Stilts 25, Snowsboes 9. Skees 7, "Jumper" 2, Skates I, Ice Boat 1 , Swing 4, Hammock I, Boxing Gloves 4, Diving Board 4, Apparatus for high jumping, Vaulting Pole, Pounding Bag, Chest Weights, Trapeze, Exerciser, one each.

By Giris:-Bean Bag I3, Ball 9, Top (spool and paper) 4, Marbles I, Bat I, Parlor Croquet Set I, Stilts (of tomato can) 5 (of wood) 3 , Snowshoes I, Swing I3, Hammock 4, See Saw I. 


\section{ARTICLES FOR USE.}

By Boys:--Picture Frames, Bookcase 3, Book Shelf 1, Writing Desk 2, Desk 1, Ink Stand 2, Shelf 2, Bracket 1, Music Rack I, Music Stand I, Blackboard 2, Pool Table I, Bench 3, Hammock Frames I, Towel Rack I, Step Ladder I, Snuff Box, Cricket I, Hen Coop 7, Pigeon House 6, Bird House 2, Bird Cage 1, Cage for Animals 4, Dog House 2, Rabbit House 2, Fly Cage 2, Squirrel House 1, Canvas Shelter I, Carpenter Shop 1 , Bicycle Stand I, Canes 5, Sun Dial 3, Fence I, Fence Picket I, Fireplace I, Furnace of Brick I, Keg I, Saw Horse 6, Sharpen Chisel I, Tool Chest 5, Weather Vane I, Candle Mold I, Bullet Mold I. Material for the most part, wood. Pictures Io, Valentines 5, Paint Flowers 1 , Drawing (failed repeatedly on some particular object) 2, Paper Hats and Caps 6, Fans (wood) 7, Chain 3, A Book I, Envelopes 2, Initials I, Horse Hair Rings I, Braid Hair (failed) 2, Sewing (failed repeatedly) 9, Compasses 2, Cotton Gin 2, Pulp Map 2, Wood Map r, Writing Book, Australian Hut, and Ruler, one each, Candy 2, Gum I.

By Girls:-Aprons 7, Dress 7, Dress Pattern 2, Crochet Dress I, Coat I, Coat Pattern I, Collar I, Sunshade 6, Trim Hat I, Straw Hat I, Quilt 5, Fan 2, Stockings 2, Mittens I, Handkerchief I, Finger Ring I, Bags 3, Lamp Mats 3, Mats 2, Blankets, Bookcase, Bureau, Ladles, Pillow Shams, Poker, Rug, "Things that are useful," one each, Valentines 18, Landscape 12, Copy Portraits 2, Sketch faces 2, Easter Eggs 2, Pictures of objects, as cat, flowers 3, Write books (attempted) 2, Write Poem I, Soldiers' Caps 4, Envelopes 3, Scrap Book 2, Ball, Book, Boat, Card Case, Fans, Fire Hat, Glove Box, Lantern, Love Boxes, Paper Pulp, Picture Book, Ring, Silver Heart, one each; material, paper. Fancy Work 135, includes Crocheting, Lace, Knitting, Sewing, and the following articles: Picture Frames, Tidies, Cushions, Pin Cushions, Pen Wipers, Dressing Case Covers, Tassels, Sofa Pillows, Bead Rings, Tray Cloth; Chains (paper and daisy) 5, Wreaths (leaves) 5, Peach stone Baskets, Fancy Bottle, Initials (cut from wood and framed), one each, Compass 2, Ruler 2, Map, Nail Map, Pulp Map, Pen from quill, School Bell, one each, Cake 7, Candy 5, Bread 2, Pie 2, Pudding 2, Ice Cream I, Lemon Candy $x$, Molasses Candy 1 .

It is not to be supposed that any one child will make all of these things. Yet some children are quite likely to make a great number of them, and the variety and care with which they are made will be an important index of the child's capacity. Most children will, however, imitate the things made by their friends, striving to do as well or better; the genius with his original work is not the type of the child any more than of the adult. Hence the necessity of much of the work being suggested by the teacher.

The most successful attempt I have ever seen at original and careful manual work in the school, was in a fifth grade in Worcester, Mass., where a bright, progressive teacher, acting on a suggestion thrown out in a public lecture by Dr. Hall, told her pupils that they might make and place on exhibition in the schoolroom anything they chose. The best example of carefully and intelligently co-ordinated work was in the Cook County Normal School. In that school, particularly in the 
lower grades, where there is greater need of supervision, the manual work is generally outlined by the teacher, and made to help out and illustrate other work of the school, while in the higher grades the pupils are allowed to make whatever they wish, provided their plans receive the approval of their teachers.

\section{The Child's Poin't of Vinw.}

No one has ever received the best reward from child study unless he has been led to a keener appreciation of childhood, and to a deeper and more genuine love for the child. The characteristics of his play may be outlined as has been done in this paper; the spirit of his play can be caught only by the person who can play with the child and enjoy the play; a touch of this spirit, however, may be found in the words of these children concerning their own amusements. In the following paragraphs quotations are made from the answers of the children.

\section{Reasons for Not Using Certain Amusements.}

"I like games. I don't like toys because they are no good." G. Io.

"Because I'm too big." G. II.

"My favorite toys are dolls, but I do not use them very much because I am getting too old for them." G. I3.

"I used to play with dolls, but I have outgrown them. I think I was about four years old when I played dolls." G. 13.

"I cannot say that I am really tired of my childhood pastimes, although, of course, I do not indulge in them now." B. I7.

"The toys I like best are Brownies, printing press, electric motor, scroll saw, Welch's steam engine, type writer, tool chest, small shot gun, and a rifle. The reason I like to play with these toys, because these are toys for bigger childten and the others are for babies and other small children. Also for another reason, you can use some of these toys and gain money on them." B. II.

"I like a ball, foot-ball, and used to like tops and marbles, but do not now. I like baseball and foot-ball because I receive much enjoyment from them, and I come together with my friends, and time is very pleasantly passed." B. I4.

"I do not use the toys that I like best because I want to save it." B. II.

"I don't play with my toys and games that I like best because I have to help my mother all the time." G. I2.

"I don't play my favorite games, because no one wants to play." G. I2.

\section{Reasons for Preferences in Amusements.}

"Marbles, Ball, Top. I don't know why I like to play those best." B. II.

"I like these toys best, because I have played with them most." B. I2.

"I have no favorite play. I play games with the other children whether I like the game or not." G. II.

"I play the game I like when the other boys want to." B. I3. 


\section{AMUSEMENTS OF WORCESTER SCHOOL CHILDREN.}

"I do what the rest happen to want to do, and I can never tell what that will be. G. I4.

"I like to spin a top because it is fun to hear it hum." B. 8 .

"I like a train of cars best because I can make them go when I run." B. 9.

"Because I like to hit the other boys' tops and break them." B. 8.

"I like to play with a pea-blower and pop a hen on a leg, and the hen goes just like a sprained leg." B. 9.

"I like to play with a gun. Sometimes I swipe my father's gun and kill birds. Once the first time I swipet it I killed my cat and the kik of it knock me down." B. Ir.

I like blocks best because I can build houses and castles with them." B. ro.

"I like swords because I heard of brave men. I like lances because I read of Mohammedans and Christians." B. 8.

"I like to play with my dolls because I make believe they are alive. I like to play with my cart because $I$ make believe $I$ am a horse and have somebody for a master." G. 8 .

"The playthings $I$ like the best to play with are my kittens, my dog. I like these the best of all because they are alive and can move; dolls cannot move nor walk, so I do not like to play with them." G. 13 .

"I like to play with a dog because the dog plays with me." B. II.

"I like to play with a doll because I can pretend it is my baby." G. 7 .

"I I like a doll, a doll carriage, a doll bed, a doll hammock, a doll trunk, a doll kitchen, a doll house and other furnishings. A bouse because it is so like a big lady and a big house." G. ro.

"I like dolls because you can make believe you are their mother, and send them away and to school, and have lots of fun. Paperdolls, because you can make pretty paper dresses for them." G. I4.

"I like to play with dolls when we are many to play, but now I don't care much for dolls. We often make party and eat in little toy dishes. I like to eat in small dishes because I think the food tastes better." G. I3.

"I like to race on foot because you can get a price." B. 8.

"I like to play marbles because you can get lots of them." B. Io.

"Bat ball. Because it makes my muscles strong." B. 8 .

"I like to ride a bicycle because your muscles will be hard." B. I3.

"I like a drum to play because if I could play so when I would be a man I would be in a band " B. I2.

"I like to play show to do tricks." B. I2.

"I like a bicycle because it makes me strong and I like to do tricks on it." B. I2.

"I like to play with my drum because all the people look at us." B. II.

"The toy that I like is fish-pond, because it shows whose hand is the most steady. I like to play checkers because it shows who has the most skill." B. I4.

"I jump rope to see if I can jump as long as the others." G. IO.

"I like to play tag because I won't get caught." G. Io.

"I like my little express to make off I am a little expressman. I have got an old cowboy's hat and a sword and I make off I am a cowboy. I go through the road with my wagon as fast as I can go, and I scare all the little fellows." B. I2.

"I like to dance so as to be in a show." G. IX.

"I like to skate because one day I can be a fancy skater." G. I3.

"I like to play a piano because we can take music lessons. Then you can go to play in the churches and in shows." G. I3. 
"The best game was tag because there was running in it." G. II.

"I like a bicycle because I can go on it very fast and race with other boys." B. II.

"I like carpenter tools best because you can make little wagons, chairs." B. II.

"I like my tool chest because I can make some little tables for my little sister." B. I3.

"I like to play checkers because my papa plays with me." G. 9 .

"I like to sew dresses on my sister's doll because I love to cut out patterns of capes, skirt, also waist, and many other things. My mother lets me sew them on the machine. I enjoy it. Sometimes she buys me some aprons and I make them myself. I love the machine very much." G. 14 .

"The reason I like these toys is that I think there is a great deal of fun in them. They take the lonesomeness away from you." G. I3.

"Such toys as checkers, dominoes and tiddledewink8, I like these toys because one can sit down and have some fun, but still be resting." G. I3.

"I like to fly kites the best. Because I do not have to be running around all the time and will not get sweaty." B. Io.

To the reader who has noted these words of children, it will be apparent that the reasons given do not always explain. But inasmuch as the most careful students have not yet evolved a satisfactory theory of play, it is no wonder that the child sometimes fails to tell just why he plays certain games. Yet on the whole, in the light of this study, some of these answers show a wonderful power of introspection, and marvellous accuracy.

As the child begins to grow beyond the normal age for a certain kind of amusement, the child assumes a scornful attitude toward it; he is "too big;" it is "a baby game," and although only last year he played it as hard as ever he could, plays it occasionally even now in thoughtless moments, it seems to him something very remote. Thus the child's estimate of the age at which he played certain games, is likely to be one or two years less than it has been shown to be. And up to a certain limit the older the child, the older it thinks it was when it last played a given amusement, e. $g$., the nine year old boys from a certain school state that they "played horse" when five years of age, the ten year olds when six or seven, those of eleven at seven, those of twelve at eight, and one boy of fourteen remembered that at eleven he still played horse.

Can any one doubt that the little boy of eleven likes best to play marbles, ball and tops, even though he is unable to tell why? Does it not seem probable that many a child likes best those things with which he "plays most?" Many a child plays but seldom with the toy he would prefer, because " sometimes one would want to play one game and some one else another," and so he "does what the rest want to do, and can never tell what that will be." Many games would be justified 
if they did nothing more than offer " an opportunity for friends to come together" so that "time is very pleasantly passed." One play may be good for a boy because he can " run," show off, "get muscle," and yet not detract from the value of a game in which "one does not get sweaty," or in which one "can enjoy oneself and rest at the same time." There is pleasure in things that "are alive," that move, that "make a noise;" there is also pleasure and profit in taking the small, inanimate toy and endowing it with life, in feeling at once its companion, its creator and its master. How many a boy who at ten years of age, feeling all over the power within him, "pops a hen on the leg," or "kills birds" or finds it "such fun to run into something" with his little express, "and tip them all out if he can," has unjustly been considered unnaturally cruel ? What a wide range and what clear backgrounds are given to his ideas as in imaginative games he builds "houses and castles," and reproduces life about him, and the past and present in history and fiction? The little eight year old runs his race to "get a price," and he likes the race. Ever since Saint Paul's day it has seemed good to "so run that ye may obtain." And these children, more and more as they approach those years when the adolescent soul yearns for the wider, richer things which it glimpses but grasps not, place before themselves something to be obtained, some end to be reached, and find a genuine, wholesome pleasure in the attempt to attain this ideal, and in the anticipation which accompanies this attempt.

\section{Application of Study.}

What is the significance of this study? That depends both on the attitude and the experience of the reader. The principal points of value are here presented as they appear to me.

Much emphasis has already been laid upon the place of amusements in the development of mental life. ${ }^{1}$ It is vastly more important that teachers and parents see that conditions are favorable for the profitable employment of the child's leisure time than that they graft "the play instinct " upon the methods used in the school. Later we shall indicate how some of the special facts brought out by this study may be utilized in the school room; now we wish to lay stress on the greatest " school of infancy," free play. From no other source does the child learn so much that is of permanent value in after life as in those hours spent in play apart from the direct influence of adults. Yet the value of this play may vary much accord-

\footnotetext{
${ }^{1}$ Compare Baldwin: Mental Development. N. Y., 1897. pp. I $29-547$.
} 
ing to conditions imposed by the child's elders. It becomes, then, the duty of parents and of society to provide that, as far as possible, the most favorable conditions shall exist for the proper kind of amusement ${ }^{1}$ at the proper time in every child's life.

It has been shown that the early part of life is largely given up to individual development, to acquiring mastery over self, and to the comprehension and mastery of the physical environment in which the child is placed. It is necessary that he should have a chance to try his strength, exercise his skill, and satisfy his curiosity and imagination in every way. $\mathrm{He}$ must have toys and objects of many different kinds which his imagination may transform in imitation of the realities about him, or upon which he can exercise his skill. Are these conditions always found?

As the child grows older human society enters more and more into his development. The influence of companions of the same age, of one's peers in actual life, is the foundation of society. This rubbing together while engaged in what are to them the realities of life, is the essential factor at the base of every rational attempt to develop in the young principles of good citizenship. Concrete examples are the George Junior Republic at Freeville, N. Y., and the scheme of self-government followed in the Chicago Normal School. In both of these exceptionally successful attempts at self-government among minors, the actual life of the community has been the foundation. Their failures have been where there was a conflict between the theoretical and the actual conditions. The school itself is in many ways an ideal social community, and may be organized along lines which touch its own life in a most effective manner. But children detect sham. The moment a school claims to be an artificial city or government which it is not, it becomes less effective in training for citizenship than if not so organized. At the George Junior Republic, where the writer spent two months in the summer of 1897 , the conditions were ideal for a community founded on the model of the United States government. The children were from a class of society where they had already faced the problems of securing an existence and met the temptation and crime. More than most children they were prepared for the rough conditions of the camp life at The Republic. It was for most of them a fairer opportunity for existence than they had hitherto enjoyed. They recognized the reality of their life under slightly changed conditions, and also, as never before, realized that they were a part of the social whole. But notwithstanding that in most respects " the citizen

1 Throughout I have used the word "amusements" as almost synonymous with " activities." 
of the Republic" was a true citizen, it was impossible to disguise the fact that at times there was a power over them which did not originate among themselves, and which at times caused many to feel that all was a sham. In a school any such diversity between the actual and pretended conditions must make itself felt injuriously. Hence the recognition by the teacher of her schoolroom as a true social body, the members of which can be led to recognize their mutual duties and privileges-a result often accomplished by a skillful teacher-is much to be preferred to any artificial government which can be formulated.

Another problem which confronted the George Junior Republic was what to do with the younger members. The majority of the citizens had already reached their teens; but the few below twelve years of age, almost without exception, did not readily adapt themselves to citizenship. Their social instincts were not fully enough developed to warrant placing upon them the full responsibilities of citizenship even in a junior republic. The problem was solved by making the younger children wards of some citizeu of twelve or more. This is empirical proof that the conditions, favorable for one age, may be unsuited to an earlier age, and is a caution against too elaborate schemes of self-government at too early an age in our schools.

Certain conditions of society tend to develop a child along one line to the neglect of another. Thus the country school while it favors the development of a strong individual character, frequently does not furnish as good an opportunity of developing co-operation as the city school; but there is more danger that the large classes of the cities may force the social development upon the child at too early an age; at an age when he is not yet ripe for it. Apart from the social demands, the needs of physical development make it most important that during the years from 9 to 12 every child should have plenty of companions, and suitable places in which to play these active running games which do so much to give final control over self, as well as the right spirit toward one's fellows. The child should also be supplied or, better, be allowed to supply himself, with those toys which tend to foster the physical exercises popular with the young at this period. Rousseau's estimate of the importance of such games is found in the following letter to D'Albert:

"In my time children were brought up in a rustic fashion, and had no complexions to keep. . . . Timid and modest before the old, they were bold, haughty, combative among themselves; they had no curled locks to be careful of, they defied one another at wrestling, running and boxing. They returned home sweaty, out of breath, torn; they were true blackguards, if you will, but they made men who have zeal 
in their hearts to serve their country and blood to shed for her. May we be able to say as much one day of our fine little gentlemen, and may these men at fifteen not turn out children at thirty." 1

This study is emphatic in its proof that one purpose of education, one of the aims of the school, is to prepare for proper employment of leisure moments. Child life is largely made up of such moments. And in no class of society do the long hours of work (often fourteen or fifteen hours per day) of our grandfathers now prevdil; as a people we can say as never before, "our time is our own." How to use this time is one of the serious problems of to-day. It will leave its trace in our physical being, in our moral and mental make-up, in national character. The increased interest in athletics of all kinds and in out-door sports during recent.years shows how this problem has forced itself forward; so, too, the many schemes for self-culture in the more favored homes, and the settlement work among the less favored districts of our large cities. The school has already done much, especially in the direction of developing "a many-sided interest," to recognize and meet this problem. Wherever literature, music, drawing, manual training, nature study, or any other branch of the curriculum has been so taught that a child bas come to appreciate more fully the richness of the world of nature and man about him, and especially when he has acquired skill enough so that along any of these lines he can do something, however slight-can give some expression to his creative powers-the school has lent its aid to the formation of habits which will influence the whole future of that child's life. With the adult, even more than with the child, amusements are habitual. Hence must the school take into consideration the effect of its work, in the formation of conditions that will affect the play of the children to-day, and determine to a large extent their habits of amusement when men and women grown. The school will either develop activities which will persist, or it will prevent, by over-stimulation of certain interests, others that ought to persist. Consider for a moment these words of an exceedingly able high school boy of fifteen, and a hard student: "I never made anything-never had time." There is something almost pathetic in these words. There is also a great deal of truth in them; for though he generally led his class, he was compelled to study early and late, and, although he was supposd to have all that indulgent parents could give, his home environment did not favor manual work of any kind.

Realizing, then, that to prepare for the right use of leisure

IMorley: Rousseau, Vol. I, p. 2 I. 
moments is one of the aims of school life, let us consider how this study may be applied, first to the course of study and then to the methods of the schoolroom; without, however, distinguishing sharply between method and content.

In many kindergariens much stress is laid upon the unity of the ring and the unity of effort, and properly so. But although much work in common may be expected of children of this age, the period has not yet arrived for advanced co-operation, and there is danger that the social ideals of an adult may be made to take the place of those natural to this period of life. This danger is especially great in an age when the popular interest in sociology is so great as at present. Yet in few other ways do the followers of the great Froebel depart from his teachings further than when they emphasize the kindergarten as the place for social development rather than individual. ${ }^{1}$ We think this study shows in its curves something of the true order of nascent periods; the order will be found to agree closely with that laid down by Froebel himself, though with greater definiteness. It shows that "boyhood" rather than "childhood" is the time when social instincts are strongest. "Boyhood" is the time when "they seek the laws lying in the material of the play, and adapt themselves to these, or they obey laws lying in the thoughts and feelings of the human

\footnotetext{
1 Prof. Colozza, of the Normal School at Naples, in his book entitled Play in Pedagogy, advocates less interference with the free play of the kindergarten child, and warns against starting the child into plays at too early an age before the natural inclination for such play has developed.

Another eminent Italian, Guiseppe Sergi, is quoted against the common practice in kindergartens by Dr. A. F. Chamberlain. (Ped. Sem., Vol. II, p. 474.) "Suggestion in education has its limits. At an age when mental activity is in process of development, certain procedures may have grave and dangerous results-the brain, continually waiting for suggestion after the first, may be arrested and remain in habitual inertia; a narrow and restricted limit of cerebral activity may be created; a species of mental parasitism may arise; too clear a road and too easy a passage may be traced out for mental activity, which will natually result in diminishing the individual mental variations which are the best advantage possible for the development of the mind and for the evolution of its products; just as in the case of the muscles, the cerebral functions, accustomed to be guided step by step, will cease to be prompt and quick, and in children there will be established real inertia, the result of hindering proper functional development. The Frobelian method is weighted down with these defects, for, while seemingly desiring to allow liberty and independence of mental activity in children, in reality it suppresses them." . . "In the use of plays and games suggested or made by the instructors, and of which the children are merely the automatic executors, the same method of suggestion continues, which ruins the natural development of the children, tends to equalize them all and to abolish all initiative and individuality."
} 
being." But of "childhood" he says: "It is impossible to establish among the various stages of human development and cultivation any definite order with reference to their relative degree of importance, except the necessary order of succession in their appearance in which the earlier is always the more important. In its place and time each stage is equally important. Nevertheless, inasmuch as it contains the development of the first points of connection and union with surrounding persons and things, the first approaches toward their interpretation and understanding toward the comprehension of their inner being, this stage (of childhood) is of paramount importance.

Therefore, the child at this period should see all things rightly and accurately, definitely and clearly; and this applies to things and objects themselves, as well as to their nature and properties. ${ }^{2}$ The following is his opinion of the effect of activities unsuited to an earlier stage of development; " $\mathrm{He}$ (the child) is much injured and weakened by having placed before himself at an early period, an extraneous aim for imitation and exertion, such as preparation for a certain calling or sphere of activity. The child, the boy, the man indeed, should know no other endeavor but to be at every stage of development wholly what this stage calls for." 8 This caution is of value higher up than the kindergarten.

The object of the first few years of school life is to further the development of the child, not to make him a full-fledged citizen. The perfect individual must precede the perfect state. Hence the first few years at school must deal largely with the immediate sensuous environment of the child and with his relation to it. He must be guided to a fuller knowledge of things around him - of what he can do with them, of what they may do to him-and this knowledge will include many of the simpler duties owed to those about him. Toys and objects of all kinds should be used freely as means of expression-to help tell the story of life about him-to help comprehend it. Much manual work should be encouraged, but it should neither be too accurate nor too delicate. Rough imitations of things about him, made of any material that is at hand and can be readily manipulated, are probably the best things to make, e. g., toy men and women, animals, houses, furniture, dresses, machines, etc. Many of these are the natural toys of childhood.

During the middle and latter part of the elementary school grades especially between the years from nine to twelve, much

${ }^{1}$ Education of Man. p. 303 .

2 Education of Man p. 50 .

8 Ibid., p. 30 . 
more attention should be given to physical development than is now common in schools. Our curves show this to be the time of greatest physical activity. Kline in his study on Truancy $^{1}$ tells how the desire to get away from the restraining influence of school and to do something has sent many a boy to the reform school. The success of the methods used in some of the most progressive reform schools, where the hours ordinarily devoted to literary subjects in our common schools are shortened and much manual work added with gratifying results, proves experimentally the soundness of this suggestion.

This is the period for the acquirement of manual skill and dexterity. The child likes to do things for the pleasure in doing, in learning to do new things and in showing that he is able to do them. At this period he should learn to do many things, should lay the foundation of skill along many lines. This is the period rich in possibilities, ripe for the formation of varied associations, according to the latest investigations of neurology.

Hence, not only should there be a great diversity of physical exercise, but a great variety of general ideas should also be apprehended in their simpler associations. Literature and nature study offer the widest possibilities along this line, and at the same time form the best content for the study of language. The meaning of ideas previously gained should be broadened, and new relations formed and new ideas introduced from a wider field. Perhaps at no time in school life should the range of the curriculum be as general.

In the next period is the birth of adolescence with all that means of new, far-reaching thoughts and feelings. Things begin to have new meanings and new purposes, and aspirations are formed-ends far away are sought. Less frequently is the activity in itself sufficient. Effort becomes concentrated. The course of study at this time should gradually become better co-ordinated into a few and more distinct groups, but should not suddenly confine the interest of the pupils to the three or four studies of the first year in the high school, as is now common. Thus to imprison the interests of the children within such narrow and forbidding walls is as unreasonable and criminal as were some of England's laws a century ago.

Although many speak of introducing the play spirit into school and of teaching everything by means of play, no one knows better than the teacher that all the child's activity is not play-in the sense of the free sportiveness of animals. Many of its amusements are serious for the child as well as for the adult. He must feel the importance of the task at hand,

1 Ped. Sem., Vol. V, p. 147. 
and the interest in the result continues to increase with every additional year.

In the earlier years before eight or nine, the largest possible use of all sorts of objects should be made. There are two main purposes which these fulfill: first, to gain new impressions, for which actual objects are preferable; secondly, as a means of expressing the stock of ideas already obtained and of broadening them. For this latter purpose, the rough imitative toys just mentioned on pages $25^{0-252}$ or pictures may be of greater value, as they can be more readily handled and comprehended by the child. Common objects such as stones, leaves, flowers, pieces of paper, burdocks, etc., may be used as furniture, building material, dishes, money, and in countless other ways to great advantage. Especially will this be possible in the rural schools, which are less able to purchase supplies of a more elaborate character; and the gain in the capacity to use material at hand will be a distinct advantage to the child when later he is compelled, with limited resources, to face the problems of life.

The next period is really one of the richest in the development of the child. If in the earlier stage the training of his senses has been thorough and his impressions many, at this period it will be possible to gather these into usable form, and through them to apperceive much knowledge which will be a foundation for future effective creative work. Considering the great variety of definite amusements at this period, and the way in which these are played, we get a clue to the method of covering the wide field demanded, without overburdening the child with a multitude of subjects at one time. It is the method of treating some particular phase of a subject quite intensively for a time, as if it were an entire field in itself, and then dropping it for something related perhaps, but in turn considered as a whole. Literature and Nature have been referred to as especially adapted to this treatment. Social tendencies should now be fostered more than before. Things made, more than earlier, should have some use to which they can be put. Mechanical toys and toys for physical exercise are well adapted for part of the manual work of this period. The possible use of things at hand, which on both an economic and an ethical basis should be encourged at all stages, should now be taught with the greatest care, for this is a period of exceptional possibilities along this line.

From the thirteenth year the child's amusements take on a decidedly co-operative and competitive character, and his efforts are more and more confined to the accomplishment of some definite aim. The course for this period will concentrate the effort upon fewer lines. A subject which on account of interest 
might better have been treated in a few days or weeks in a lower grade, may now well occupy several months of more careful and deeper study. The result now demands greater attention, and the best work should always be insisted upon. Societies and associations of all kinds which favor this co-operation to accomplish some worthy end are to be encouraged now as never before. Nor can this well be separated from the spirit of emulation which has been found to be so characteristic of this period. A trait so prominent certainly justifies the Roman Quintilian in placing the love of emulation among the most important feeling upon which the teacher has a right to call; for it is only through the desire to do or make something, to show one's superiority or power over something or some person, to overcome some obstacle, that the individual, the nation, or the race makes progress. This same desire for mastery is present in fullest strength just at this age. It is the basis of the healthy rivalry of members, most often of a small group, in which each takes pride in the superior quality of his work. The same thing fostered by machine promotions, becomes the feverish pursuit of "marks" so often found in large schools where it appears not as a friendly contest with one's peers for acknowledged superiority giving constant opportunity for pride in personal merit, but a blind struggle to attain another enda "passing mark." On the one side it develops " a pride $o$ ' worth " and the power to maintain one's self independently, and without asking odds; on the other, when the end receives too much emphasis, are found the seeds of dishonesty. The system of ranking, so prevalent in the great public school systems, makes it possible to find many, perhaps the majority of the pupils look upon the attaining of a set mark in their studies as the highest aim of their school work; to find principals who place a report containing few records of discipline or absence above the mental and physical health of their pupils, and superintendents who insist upon these conditions in order that their reports may be pleasing to the people.

There is no reason why throughout the course much of the work to be done should not be the making of toys such as children commonly use. The character of these will be seen more specifically by examining the list of things made. In the earlier years these will be for the most part simple representations of the living and inanimate things about them; later on may be made to advantage toys which are means of developing strength or skill, as for example those used in baseball or football; and still later will come the making of articles of use in themselves, as for decoration, use at home, etc. This rough division is not intended to be exclusive, as all classes of articles are likely to be made more or less at each stage; thus the 
smaller children may make some of the simpler toys used by them for exercise, and many simple articles of use.

A few easy general plans are here offered by way of suggestion. One of the most promising fields is in the making of dolls, their dresses and furniture. This may be done by the pupils individually, each making articles for which it has some definite use, or by the co-operation of the whole room to fit out one doll as was done so successfully in the school in St. Paul, described by Miss Stoker. ${ }^{1}$ The pupils of this particular school averaged fourteen years of age, and took the greatest possible interest in making something and in co-operating to secure a common result. With girls of this age or slightly younger, paper dolls and dresses might have been used to considerable extent, and advantage taken of the instructive pleasure in parties at this stage, to develop correct ideas of general social duties, and to interest in the principles of domestic science. Besides the families of paper dolls which may be made, it would be well to make table sets, tables and chairs, and eventually to have small dinner parties which might serve in many particulars for the model of those which all girls so much enjoy and play. These lessons should be suggestive to the extreme, and lay emphasis upon correct ideals.

In many schools the children already make small models to illustrate the subject studied, and in some these objects are utilized in the toy theater to dramatize the stories of which they read. Work of this sort may easily be made much more general than it is. The list of things made cannot fail to suggest many possibilities. Neither is there any reason why the teacher should not at times suggest the work of the children, though as far as possible they should be free to choose and to allow their own originality to develop. But the original child, the genius, is not the average child. Left to itself a child is likely to imitate some one else; hence it is often better in the lower grades that the teacher should select.

The value of the out-door habit, and of everything which tends thereto, cannot be too strongly urged. "The fresh air habit, at home and in the school, is the most wholesome bodily habit that can be implanted at the school age," writes President Eliot, of Harvard. ${ }^{2}$ Much of the school work readily adapts itself to the formation of such habits. Nature study as taught does much, but should do more. One of the greatest values of collection is on this account. The collections which the child makes of stones, leaves, flowers, seeds, insects, etc., may not be of much value in themselves, but few motives can interest

Ped. Sem., Vol. V, p. $28 \mathrm{r}-286$.

2 Educ. Rev. Dec.' 97, Vol. XIV, p. 417 . 
a child more in things about him than the possibility of himself possessing them. Thus the passion for possessing takes the child to things which he should know and love; later throughout his whole life he will recognize with thrills of pleasure these old friends, and recall the exact spots where once long ago he found this or that in rich abundance. School walks, too, are of value sometimes, but in many cases, especially in rural communities, are likely to be mere subterfuges to get rid of school duties, and thus merely teach the possibility of shirking resposibilities; for the city children to whom the fresh country is always a rich treat this does not apply equally. But much better than any general walks may be the formation of walking clubs, picnic clubs, bicycle clubs, etc., which at stated intervals visit convenient places of interest.

Teachers may also refresh the interest of their children in being out of doors by the introduction of some new game. The best game to introduce is some game you used to play and especially enjoy; better still, if you can now enjoy it. Often it is no easy thing to introduce a new game as in many places the local traditions and conditions already so strongly favor certain games that others are not needed; and failure to succeed in such attempts ought not to discourage. On the other hand it is possible to find children with very scanty repertoires of games, and largely on account of their environment ignorant of the most common games. The writer can hardly imagine boyhood where the boys do not know how to play baseball. Yet it is said that when a certain play-ground was opened a few years ago in the neighborhood of a slum district in Boston, and the materials for the game supplied, the boys did not play until they had been taught the game by the attendants. On account of the limited number of associates of his own age the average country child knows fewer of the traditional games than his contemporary in the more favored parts of the city.

Children's descriptions of things they have made and the plays they have played form one of the richest fields for composition work, and one which has as yet been but slightly worked. It touches upon the most vital part of their life, and besides furnishing an interesting and rich subject for composition, reveals to the teacher much of child life with which she should be in sympathy, It could not but help and inspire her own work for her pupils. A careful study of the way children play such games as school and house, made in this manner, would contribute much to our present knowledge of the child.

Owing to the peculiar character of the returns forming the basis of this study there is danger that its true value will be underestimated by some, while others will give too great significance to the results presented. In the early part of this 
article attention was called to the nature of these returns. They came from different schools as differently environed as it was possible to find in Worcester. Different teachers collected them; some talking the questions over with their pupils, and some merely giving the questions and having the answers written at once. The possibility of suggestion and the consequent unreliability of the returns at once occurs to any one who has tested the tendency to imitation, so strong in children. Accordingly the writer did not at first appreciate their true significance, particularly as they had been secured for the purpose of answering certain questions which had arisen in another study; and only after a careful examination was it realized that in an unusual manner they brought out the general characteristics of child activity, and were exceptionally reliable.

The questions were so framed that as far as possible they called up the child's own experience without suggesting any particular answer; the tabulated result did not depend on any one answer, but was a composite of a dozen or more answers, in the same return, to questions from different standpoints; and, as far as the general tendencies of child activity are concerned, the internal evidence of the papers, and the comparison with such other facts as are obtainable, favor their reliability. The evidence of suggestion was not so strong as would be at first naturally expected, and the little that was found did not materially influence the facts concerning a general activity or concerning any popular amusement. Grounds for this assertion will be found by comparing the list of questions asked with the Curves of Interest in Traditional Anusements ( $p$. 228). Though these curves are compiled from the answers to over a dozen different questions, only between nine and fourteen years does the average number of different amusements mentioned exceed ten. Evidence of a minimum of suggestion is also found in the fact that the papers, as a rule, agreed chiefly on those amusements popularly known to be among the most common, and that the relative number of children mentioning them-e. $g$., about 67 per cent. in the case of dolls and ball play -is apparently too small; on the other hand, they differed extremely in the less common amusements, as is shown by a total of over 700 different ones mentioned by these 2,000 children, who cite on an average only ten different ones.

These results, then, represent with approximate correctness the general characteristics of the amusements of 2,000 school children in Worcester. Local conditions and other causes in their environment, such as their school life, have undoubtedly influenced their choice of amusements, yet these children repre- 
sent average American children, and these results are typical of their normal activity.

\section{BIBLIOGRAPHY.}

A few selected titles are here given, but only such as are likely to be most helpful to the reader wishing to make further investigations along this line. Of works descriptive of many of the games mentioned in this article, Newell is, perhaps, the best of any one authority. He gives a good description of many of the traditional games of America; shows how they may vary in detail in different localities, and yet retain the essential features; and he accounts for the remote origin of many amusements. Of similar value is Miss Gomme's Traditional Games of England, Scotland and Ireland. Such general works as Champlin, Cassell, and Routledge's also describe many of these games and some of the other forms of amusement common among the young. Misses Gomme and Willard have each collected a few of the more common singing games of children, giving the music as well as the words. Since Babcock and Culin found in Washington and Brooklyn many of the games now popular in Worcester, their description will be of special interest to the reader of this article.

For the discussion of the theory and psychology of play the reader is referred to Groos, chapters I and V of the Play of Animals and the same author's more recent work, Die Spiele Menschen. Groos gives the fullest and clearest treatment of this subject to be found, and his bibliography in the foot notes is very full. The function of human play is also discussed by Baldwin. The references, already given to Froebel, James, and Wundt, account for some of the different phenomena observable in the play of childhood. Dr. Gulick gives the results of his own careful observations. Newell finds many of these games merely the inheritance of the ceremonies and amusements of adults at an earlier period; Culin associates many of them with the ceremonies of divination; while Taylor sees in these plays and movements of childhood the recapitulation of primitive life and its movements; and Burk in teasing and bullying sees a phase of the same tendency.

La Grange has published what is perhaps the most complete study of physical exercise; while Keating and Ralfe have each put in more popular form the accepted opinions upon the results of physical exercise. Beyer in his study of the cadets at Annapolis has made the most important contribution in English regarding the effect of exercise in growth. The general attitude of those interested in physical training is well seen in the admirable discussion of the different systems of physical culture found in the Report of the U. S. Bureau of Education for 
1891-92. A progressive modern view of physical education is given in Dr.Hartwell's paper mentioned in the bibliography. Lesshaft and Bierent touch upon the physiological effects of physical activity during the years of childhood; while Burk's article, From Fundamental to Accessory, presents the more recent opinions concerning the development of the nervous system.

Comenius, Froebel, Richter and many others among the educational writers, have commented upon the peculiar value of play. Froebel more than others has recognized and attempted to take advantage in education of the play instinct. Johnson has gone a step farther in suggesting a much wider use of the game in the school. Sergi and Colozza have studied play from the psychological and pedagogical points of view, and both criticize the artificialities of modern Froebelianism. Hall and Ellis have shown the great role the doll plays in the psychical development of the child, and suggest its use in the schoolroom. Miss Blow upholds the symbolic side of the kindergarten system.

Russell's observations and the accompanying study by Miss Frear deal with imitative play. Strutt and Fettis give excellent pictures of the amusements of England and Scotland in the past. The most complete account of physical exercise and related topics, especially of the German system of gymnastics, is Euler's encyclopædia.

The following brief list of selected titles should be supplemented by reference to the bibliographies of Chamberlain, Johnson, and Miss Sisson, and the Bibliography of Child Study by Louis $\mathrm{N}$. Wilson.

BABCOCK, W. H. Games of Washington Children. American Anthropologist, July, 1888, Vol. I, pp. 243-284. Also in Lippincott's Magazine, May, 1886, Vol. XXXVIL, pp. 239-257.

Batdwin, J. Mark. Social and Ethical Interpretation in Mental Development. A Study in Social Psychology. N. Y., 1897. pp. 574.

BEYER, HENRY G. Influence of Exercise on Growth. Jour. of EXperimental Medicine, Vo1. I, Pp. 546-558. Also the Am. Phys. Rev., Vol. I, pp. 76-87.

Bilrent, Líon. La Puberté chez l'homme et chez la femme. Paris, I896. pp. 200 .

Blow, Susan E. Symbolic Education. A Commentary on Froebel's Mother-Play. N. Y., I894.

Bowditch, H. P. The Growth of Children. Report of the State Board of Health of Massachusetts. Boston, 1877 .

Burk, Frideric. From Fundamental to Accessory in the Development of the Nerrous System and of Moveinent. Ped.Sem., Vol. VI, Pp. 5-64.

—_. Teasing and Bullying. Ped. Sem., Vol. IV, pp. 336-37I. 
CASSELL. Book of Out-door Sports and In-door Amusements, Card Games, and Fireside Fun. London, I88I.

CHAMBERIAIN, A. F. The Child and Childhood in Folkthought. N. Y., 1896. pp. 464. Bibliography, very helpful. See p. 405.

Champin J. D., and Bostwick, A. E. The Young People's Encyclopedia of Games and Sports. N. Y., 1890.

Colozza, A. Il Giuoco nella Pedagogia. Torino, 1895. Vol. XIV, pp. 288.

Comenrus, J. Amos. Comenius's School of Infancy. An essay on education during the first six years. Edited by W. S. Monroe. Boston, 18g6. pp. r6-99.

Culin, Stewart. Korean Games with notes on the corresponding games of China and Japan. Univ, of Penn., Phil., 1895. pp. 36-177. See preface.

- - - Street Games of Boys in Brooklyn. Jour. of Am. Folklore, July-Sept., 1891, Vol. IV, pp. 22 I-237.

Eli.is, A. C., and Hall, G. Stanley. A Study of Dolls. Ped. Sem., Vol. IV, pp. I29-I75.

EULER, CARI. Encyclopädisches Handbuch des gesamten Turnwesens und der verwandten Gebiete. Wien und Leipzig, I894. 2 Vol.

FetTIS, RoBert S. Sports and Pastimes of Scotland. London, I89I. pp. 212.

Frear, Caroline. Ped. Sem., Vol. IV, pp. 382-386.

Froeber, FrIedrich. The Education of Man. Translated by W. N. Hailmann. N. Y., r8g6. pp. 332 .

Gomme, Alice B. Children's Singing Games, with the tunes to which they are sung. N. Y., I894. Pp. 70 .

- The Traditional Games of England, Scotland, and Ireland. London, 1894.

Groos, KarL. The Play of Animals. Translated by Elizabeth $L_{\text {. }}$. Baldwin, with preface by J. Mark Baldwin. N.Y., 1898 . pp. 26-34r.

- - Die Spiele der Menschen. Jena, 1899. pp. $53^{8}$.

Gulick, Luther. Some Psychical Aspects of Physical Exercise. Pop. Sci. Mo., Vol. LII, pp. 793-808 (Oct. 1898).

- - Psychological, Pedagogica1, and Religious Aspects of Group Games. Ped.Sem., Jan., 1899 .

Hartwel, E. M. Physical Training. Its Function and Place in Education. Am. Phys. Educ. Rev., Vol. II, pp. I33-154.

Johnson, G. E. Education by Plays and Games. Ped. Sem., Vol. III, pp. 132-I33.

Kaating, J. M., and Young, J. K. Physical Development. See Vol. IV, pp. $24 \mathrm{I}-324$.

- - Cyclopedia. The Diseases of Children. Phila., 189I.

La Grangh, Fernand. Physiology of Bodily Exercise. N. Y., I896. pp. 395.

LesshaF'T, P. De 1'Éducation de l' Enfant dans la Famille et de sa Signification. Paris, 1894 .

Newell, Writiam W. Games and Songs of American Children. N. Y., I884. pp. 242.

PARKES, Lours C. Hygiene and Public Health. 5th Ed. London, I891. pp. 557 . 
RALFF, C. H. Exercise and Training. N. Y., 1894. pp. 96.

Report of U.S. Commissioner of Education, 1891-1892. Vol. I, p. 636 . Physical Education I. Historical Sketch. 2. Essential Features of Principal Systems represented in this country. 3. Suggestions concerning School Gymnastics.

ROUTLEDGE, E. Every Boys' Book: a complete Encyclopedia of Sports and Amusements. London, I88r. pp. 904.

RussmLL, E. H. Child Observations. First series: Imitation and Allied Activities. Edited by Miss Haskell. Boston, 1895 .

Shrgr, GuishPpe. Dolore e Piacere Milano, I894. XV, 395 PP. Pages 273-284 on Play.

Sissor, Grineva. Bibliography of Children's Games. In Barnes's Studies in Education. No. 5. pp. $184-189$. Sanford University, I896. Refers to 23 books and articles, and to syllabi. Indicates character of each.

Strutr, Josape. The Sports and Pastimes of the People of England. . . from the earliest period to the present time. New Edition by Wm. Howe. London, 1845. pp. 420 .

TyLor, E. B. Primitive Culture. N. Y., 1874 .

West, G. M. The Anthropology of Anerican School Children. International Congress of Anthropology. Chicago, 1894 . pp. $50-58$.

WILLARD, El,EANoR W. Children's Singing Games. N. Y., 1895. pp. 67.

Wrtson, Lours N. Bibliography of Child Study. Ped. Sem., Vol. V, pp. 54I-589. Contains 641 titles, and is carefully indexed for convenient reference. 